\title{
Erupted cumulate fragments in rhyolites from Lipari (Aeolian Islands)
}

\author{
Francesca Forni $^{1} \cdot$ Ben S. Ellis ${ }^{1}$ Olivier Bachmann ${ }^{1} \cdot$ Federico Lucchi $^{2}$ • \\ Claudio A. Tranne ${ }^{2} \cdot$ Samuele Agostini $^{3} \cdot$ Luigi Dallai $^{3}$
}

Received: 6 May 2015 / Accepted: 22 October 2015 / Published online: 17 November 2015

(C) Springer-Verlag Berlin Heidelberg 2015

\begin{abstract}
Over the last $\sim 267 \mathrm{ky}$, the island of Lipari has erupted magmas ranging in compositions from basaltic andesites to rhyolites, with a notable compositional gap in the dacite field. Bulk geochemical and isotopic compositions of the volcanic succession, in conjunction with major and trace elemental compositions of minerals, indicate that the rhyolites were dominantly generated via crystal fractionation processes, with subordinate assimilation. Radiogenic $(\mathrm{Sr}, \mathrm{Nd}$, and $\mathrm{Pb})$ and stable $(\mathrm{O})$ isotopes independently suggest $\leq 30 \%$ of crustal contamination with the majority of it occurring in mafic compositions, likely relatively deep in the system. Within the rhyolites, crystal-rich, $\mathrm{K}_{2} \mathrm{O}$-rich enclaves are common. In contrast to previous interpretations, we suggest that these enclaves represent partial melting, remobilization and eruption of cumulate fragments left-over from rhyolite melt extraction. Cumulate melting and remobilization is supported by the presence of (1) resorbed, low-temperature minerals (biotite and sanidine), providing the potassic signature to these clasts,
\end{abstract}

Communicated by Othmar Müntener.

Electronic supplementary material The online version of this article (doi:10.1007/s00410-015-1201-0) contains supplementary material, which is available to authorized users.

Francesca Forni

francesca.forni@erdw.ethz.ch

1 Institute of Geochemistry and Petrology, ETH Zürich, Clausiusstrasse 25, 8092 Zurich, Switzerland

2 Dipartimento di Scienze Biologiche, Geologiche e Ambientali (Sezione di Geologia), Università di Bologna, P.zza di Porta S. Donato, 1, 40126 Bologna, Italy

3 CNR, Istituto di Geoscienze e Georisorse, Via G. Moruzzi 1, 56124 Pisa, Italy
(2) reacted Fo-rich olivine, marking the presence of mafic recharge, (3) $\mathrm{An}_{38-21}$ plagioclase, filling the gap in feldspar composition between the andesites and the rhyolites and (4) strong enrichment in $\mathrm{Sr}$ and $\mathrm{Ba}$ in plagioclase and sanidine, suggesting crystallization from a locally enriched melt. Based on Sr-melt partitioning, the high-Sr plagioclase would require $\sim 2300 \mathrm{ppm} \mathrm{Sr}$ in the melt, a value far in excess of $\mathrm{Sr}$ contents in Lipari and Vulcano magmas (50-1532 ppm) but consistent with melting of a feldsparrich cumulate. Due to the presence of similar crystal-rich enclaves within the rhyolites from Vulcano, we propose that the eruption of remobilized cumulates associated with high- $\mathrm{SiO}_{2}$ rhyolites may be a common process at the Aeolian volcanoes, as already attested for a variety of volcanic systems around the world.

Keywords Aeolian Islands · Assimilation-fractional crystallization $\cdot$ Cumulates $\cdot$ Lipari $\cdot$ Rhyolite

\section{Introduction}

The genesis of intermediate to silicic magmas has been a topic of debate in igneous petrology for more than a century (Bunsen 1851; Harker 1909; Daly 1925; Bowen 1928). Broadly, the discussion revolves around whether evolved magmas are generated predominantly via crustal melting (e.g., Price et al. 2005; Smith et al. 2006; Christiansen and McCurry 2008; Schmitt and Hulen 2008; Tamura et al. 2009; Simon et al. 2014) or whether they are predominantly made via fractionation with limited degrees of assimilation (e.g., Bacon and Druitt 1988; Halliday et al. 1991; Geist et al. 1995; Hildreth and Fierstein 2000; Lindsay et al. 2001; Haase et al. 2006; Peccerillo et al. 2007; Bachmann and Bergantz 2008). Volcanic suites with strongly 
bimodal erupted compositions ('Daly gaps') remain a key location for testing fractionation-dominated and crustal melting-dominated scenarios (Brophy 1991; Francalanci et al. 1995; Thompson et al. 2001; Peccerillo et al. 2003; Szymanowski et al. 2015). Proponents of crustal melting interpret the lack of intermediate compositions to indicate that the evolved compositions are not generated via intermediates (e.g., Chayes 1963; Bohrson and Reid 1997; Trua et al. 1999; Wiesmaier et al. 2012). Alternatively, recent models coupling fluid dynamics, geochemistry and thermal constraints indicate that compositional gaps may be generated via efficient crystal-liquid separation at relatively high crystal fractions (Brophy 1991; Mushkin et al. 2002; Dufek and Bachmann 2010). In such a scenario, highly evolved and crystal-poor caps can be produced by melt extraction from crystal-rich mushes of intermediate composition, which represent long-lived, thermally buffered 'rhyolite nurseries' (Bachmann and Bergantz 2004; Hildreth 2004; Cooper and Wilson 2014). Finding cumulate lithologies with a "silicic" signature would strongly support the claim that melt extraction from shallow evolved mushes is commonplace. In silicic plutons, such cumulate signatures are not rare (e.g., Bachl et al. 2001; Deering and Bachmann 2010; Gelman et al. 2014; Lee and Morton 2015), but it is clearly more challenging to find them in volcanic units, in which crystal-rich lithologies should not be eruptible, although some have been described from large ignimbrites (e.g., Bacon and Druitt 1988; Deering 2009; Deering et al. 2011b; Bachmann et al. 2014; Ellis et al. 2014; Wolff et al. 2015).

In this context, the volcanic succession of the island of Lipari, characterized by the occurrence of calc-alkaline rhyolites with crystal-rich potassic enclaves and cordierite-bearing dacites with a clear crustal isotopic signature, represents a key location to investigate the contributions of the different processes involved in the genesis of silicic magmas. In this paper, we combine petrographic information, bulk-rock data (both from new samples and published work) with mineral compositions and geochemical models, in order to characterize silicic magmas on Lipari, including the remarkable crystal-rich enclaves that occur in several of the crystal-poor rhyolitic units.

\section{Geological background and magmatic history of Lipari}

The Aeolian archipelago (active since $\sim 1.3 \mathrm{Ma}$ ) is a volcanic arc constructed upon the $\sim 15-25 \mathrm{~km}$-thick continental crust of the Calabro-Peloritano basement and located in the Southern Tyrrhenian Sea at the boundary between the African and the Eurasian plates (Piromallo and Morelli 2003). The seven islands and several seamounts comprising the arc exhibit compositions spanning from arc tholeiites (in the seamounts) to potassic rocks. Calcalkaline (CA) and high-K calc-alkaline (HKCA) rocks are the most abundant throughout the arc, and dominate the volcanic succession at Alicudi, Filicudi, Salina, Lipari and Panarea. Shoshonites are spatially restricted to Vulcano and Stromboli (and subordinately to Panarea), where these potassic rocks characterize the mature stages of volcanic activity (Peccerillo et al. 2013 and references therein). High-SiO $\mathrm{S}_{2}$ rhyolitic magmas $\left(\mathrm{SiO}_{2}>70 \%\right)$ are only present at Salina, Lipari, Vulcano and subordinately at Panarea.

Lipari, the largest of the Aeolian Islands, has grown since $\sim 267 \mathrm{ka}$ through nine successive eruptive epochs (EE), interrupted by periods of volcanic quiescence (Fig. 1) (see Forni et al. 2013 for a full description). Pyroclastic rocks and lavas on Lipari vary from CA and HKCA basaltic andesites to rhyolites with a notable compositional gap between the dacites and the rhyolites (Fig. 2). CA and HKCA basaltic andesites (with subordinate andesites and dacites) were dominant through the EE 1-4 (267-114 ka) when volcanic activity was linked to a series of monogenetic and polygenetic volcanic centres mainly located in the western and central sectors of the island (Figs. 1,2). HKCA andesites and minor dacites (including the cordierite-bearing lavas), related to the activity of M. S. Angelo and $\mathrm{M}$. Chirica stratocones, became ubiquitous during the EE 5-6 (105-81 ka) (Figs. 1, 2). Rhyolitic products were erupted during the EE 7-9 (from 43 ka to AD 1220), when volcanic activity resumed after a 40 ky-long period of quiescence (Figs. 1, 2). HKCA andesitic to dacitic grey and banded pumices occur within the M. Guardia pyroclastic sequence (EE 8) (De Rosa et al. 2003). Latitic, trachytic and HKCA andesitic crystal-rich enclaves have been frequently recognized within the rhyolitic lavas of EE 7-9 (Gioncada et al. 2003, 2005; Davì et al. 2010; Forni et al. 2013) (Fig. 2). Notably, bulk-rock grey and banded pumices and crystal-rich enclaves-bearing lavas must be considered as mixed/mingled samples rather than pure compositions (Fig. 2).

CA and HKCA basaltic andesites and HKCA andesites (EE 1-4 and 6) contain plagioclase, clinopyroxene and minor olivine, with orthopyroxene, Ti-magnetite and apatite only occurring in the andesitic rocks (Forni et al. 2013). Cordierite-bearing lavas (EE 5) are highly porphyritic rocks (up to $50 \%$ crystals including plagioclase, clinopyroxene, orthopyroxene, cordierite, garnet and minor ilmenite, andalusite, spinel, biotite and sillimanite along with a large quantity of metapelitic and gabbroic xenoliths; Barker 1987), being interpreted as derived from mixing between a basaltic-andesitic magma and a high- $K$ peraluminous rhyolitic melt of anatectic origin (Di Martino et al. 2011). CA rhyolites (EE 7-9) instead are crystal-poor $(<5 \%$ 


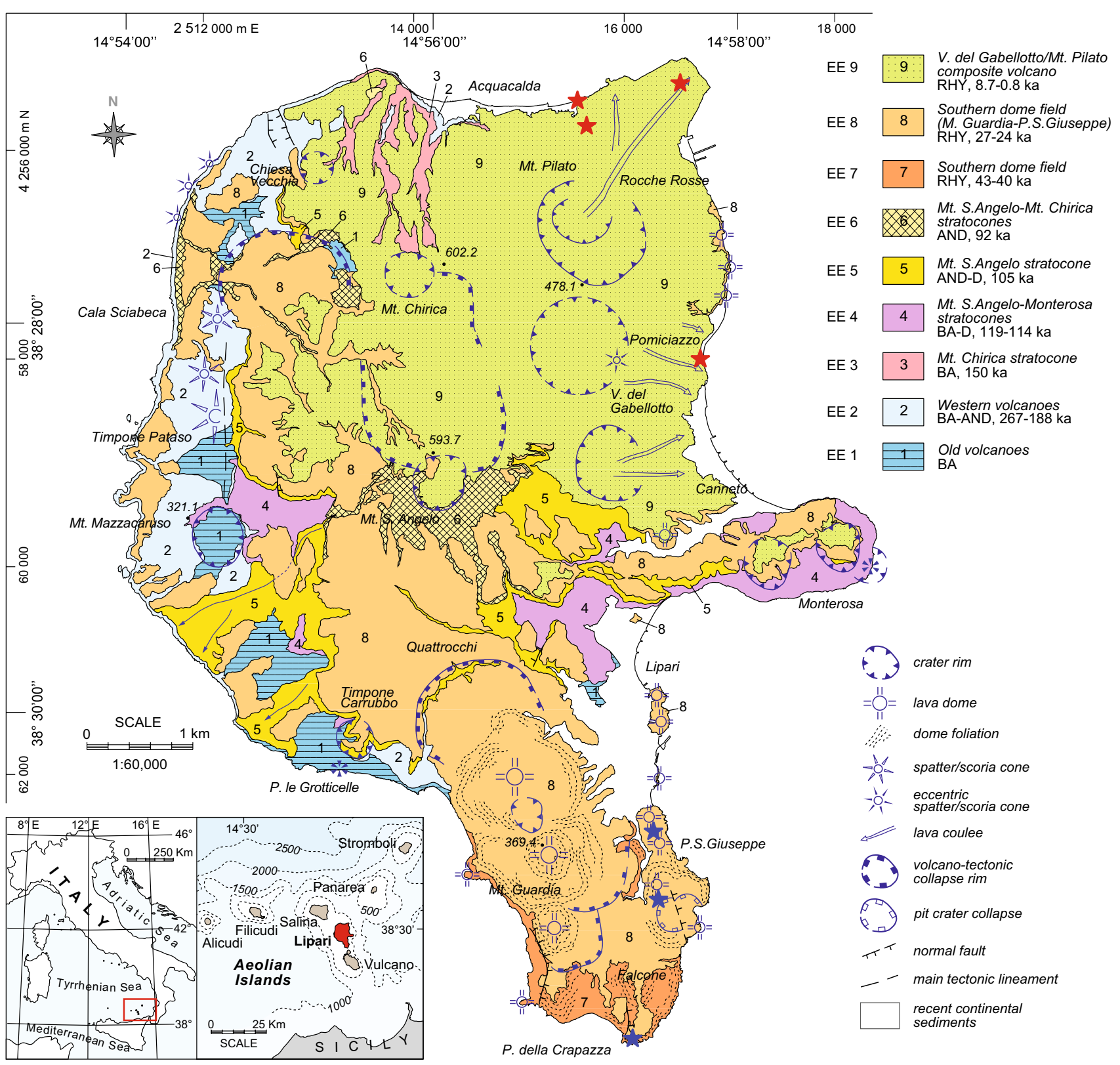

Fig. 1 Geological sketch map of Lipari Island (modified after Forni et al. 2013) showing the main stages of its eruptive history ( $E E$ eruptive epochs) and the sampling localities for crystal-rich enclaves (red

crystals) and contain K-feldspar, plagioclase and sporadic hornblende and biotite with zircon and apatite present as accessory minerals (Gioncada et al. 2003; Forni et al. 2013). Within several CA rhyolitic units, two different types of dark-coloured porphyritic enclaves ( 15-35\% crystals) have been reported: (1) andesitic and dacitic to latitic enclaves (low-K enclaves) containing plagioclase, clinopyroxene, olivine, apatite and magnetite (Gioncada et al. 2003, 2005; Forni et al. 2013) and (2) latitic to trachytic enclaves (high-K enclaves) with a mineralogy of stars high-K enclaves; blue stars low-K enclaves). Ages and compositions of Lipari volcanics are reported in the legend ( $B A$ basaltic andesites, $A N D$ andesites, $D$ low- $\mathrm{SiO}_{2}$ dacites, $R H Y$ rhyolites)

clinopyroxene, plagioclase, sanidine, olivine, biotite and magnetite with accessory apatite and zircon (Davì et al. 2009, 2010) (Fig. 3).

\section{Methods}

Bulk rock and groundmass major and trace element compositions for the crystal-rich enclaves (Fig. 1) were determined by XRF and ICPMS at University of Bologna and 
Fig. $2 \mathrm{~K}_{2} \mathrm{O}$ versus $\mathrm{SiO}_{2}$ classification diagram (Peccerillo and Taylor 1976) and frequency distribution histogram of bulkrock $\mathrm{SiO}_{2}$ for the volcanic rocks from Lipari. Grey symbols indicate data from De Rosa et al. (2003), Gioncada et al. (2003), Davì et al. (2010), Forni et al. (2013), whereas coloured symbols refer to data from this study. $E E$ eruptive epoch

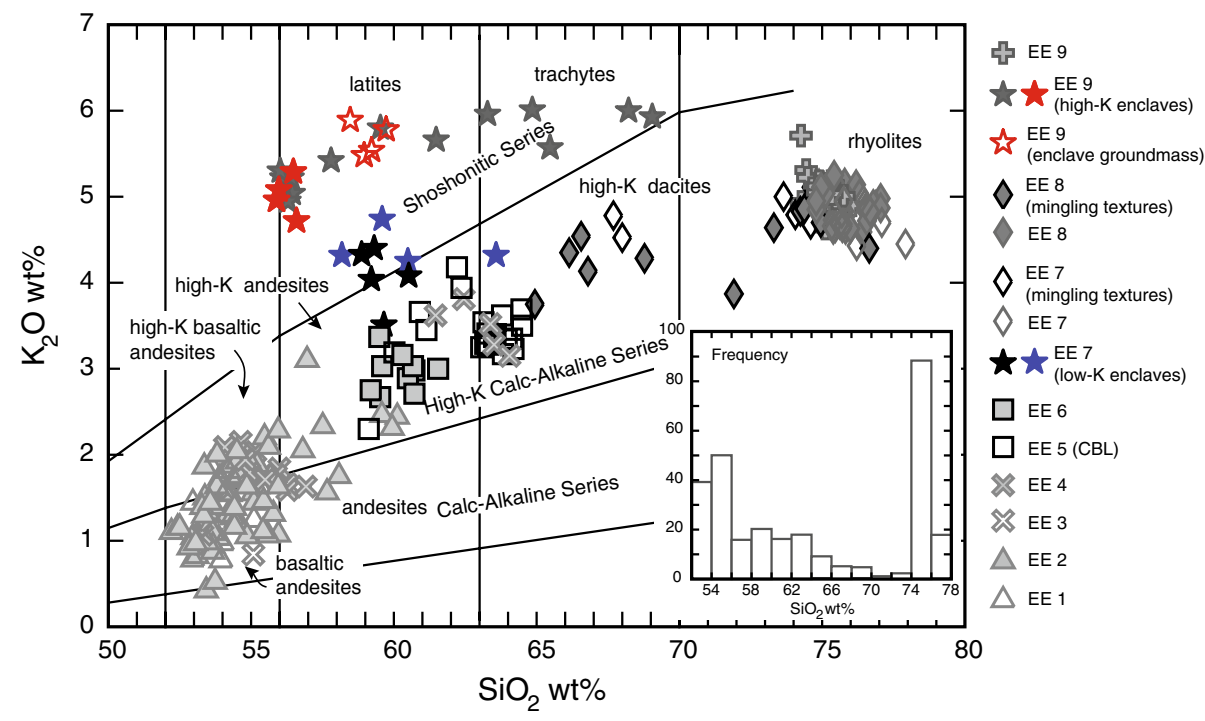

ETH Zurich. A set of samples representative of the basaltic andesites to rhyolites and crystal-rich enclaves (EE 1-9) were analysed for mineral chemistry via field emission electron microprobe at the Centre for Experimental Mineralogy, Petrology and Geochemistry (Uppsala University, Sweden). The operating conditions were as follows: $10 \mathrm{nA}$ beam current, $15 \mathrm{kV}$ accelerating voltage, counting times of $10 \mathrm{~s}$ on peaks and $5 \mathrm{~s}$ on background positions. The beam size was focused $(1 \mu \mathrm{m})$ for the analyses of pyroxene, olivine, biotite and oxides and enlarged to $5 \mu \mathrm{m}$ for feldspars in order to minimize alkali migration. Analyses were typically reproducible to $<5$ relative wt $\%$ for all major and minor elements.

Trace element concentrations in pyroxenes, plagioclases, biotite and olivine were determined by LA-ICPMS using a $193 \mathrm{~nm}$ Resonetics ArF excimer laser coupled to a Thermo Element XR ICP mass spectrometer at the Institute of Geochemistry and Petrology, ETH Zurich. Analytical conditions were identical to those described in Szymanowski et al. (2015) and data reduction employed the MATLAB-based program SILLS (Guillong et al. 2008) to determine concentrations from transient signals. USGS reference glass GSD$1 \mathrm{G}$ was used as secondary standard to monitor the accuracy of the instrument. Long-term laboratory reproducibility of homogenous glass standards indicate precision significantly better than 5 relative $\%$ for elements whose concentration was much greater than the limit of detection.

Bulk rock $\mathrm{Sr}, \mathrm{Nd}$ and $\mathrm{Pb}$ isotope ratios were determined at CNR-Istituto di Geoscienze e Georisorse (Pisa, Italy) by TIMS techniques using a Finnigan MAT 262 multicollector mass spectrometer running in dynamic $(\mathrm{Sr}$ and $\mathrm{Nd})$ and static $(\mathrm{Pb})$ mode. The measured ${ }^{87} \mathrm{Sr} /{ }^{86} \mathrm{Sr}$ ratios have been normalized to ${ }^{86} \mathrm{Sr} /{ }^{88} \mathrm{Sr}=0.1194$ and ${ }^{143} \mathrm{Nd} /{ }^{144} \mathrm{Nd}$ ratios to ${ }^{146} \mathrm{Nd} /{ }^{144} \mathrm{Nd}=0.7219$. During the measurement period, the mean measured value of ${ }^{87} \mathrm{Sr} /{ }^{86} \mathrm{Sr}$ for the NIST-SRM 987 standard was $0.710242 \pm 0.000013(2 \mathrm{SD}, N=25)$, while the mean ${ }^{143} \mathrm{Nd} /{ }^{144} \mathrm{Nd}$ for the La Jolla standard was $0.511847 \pm 0.000008(2 \mathrm{SD}, N=25)$. The JNdi- 1 standard (Tanaka et al. 2000) was also analysed and yielded a ${ }^{143} \mathrm{Nd} /{ }^{144} \mathrm{Nd}$ value of $0.512100 \pm 0.000010(2 \mathrm{SD}, N=25)$. The total procedure blanks, 0.5 and $0.1 \mathrm{ng}$ of $\mathrm{Sr}$ and $\mathrm{Nd}$, respectively, were negligible for the analysed samples. $\mathrm{Pb}$ was extracted by chromatographic ion exchange in Dowex 1 anion resin, using standard $\mathrm{HBr}$ and $\mathrm{HCl}$ elution procedures. Replicate analyses of $\mathrm{Pb}$ standard NIST-SRM 981 indicated that $\mathrm{Pb}$ isotope ratios are accurate to within $0.025 \%$ (2SD) per mass unit, after applying mass discrimination corrections of $0.14 \pm 0.01 \%$ per mass unit relative to the reference composition from Todt et al. (1993). The $\mathrm{Pb}$ blank varies from about 0.4 to $0.6 \mathrm{ng}$, and no blank correction was made.

Oxygen isotope compositions of mineral separates were obtained at CNR-Istituto di Geoscienze e Georisorse (Pisa, Italy) by laser fluorination technique (Sharp 1990) reacting the samples under $F_{2}$ gas atmosphere. Purified oxygen gas was directly transferred into a Finnigan Delta Plus Mass Spectrometer via 13A zeolite molecular sieve for isotopic ratio determinations (Sharp et al. 1995). All the data are given following the standard $\delta$ notation. All samples have been duplicated with analytical precision of $\pm 0.2 \%$ or better. During the course of analysis, an in-house laboratory standard was used (QMS quartz; $\delta^{18} \mathrm{O}=14.05 \%$ ), yielding an average $\delta^{18} \mathrm{O}=14.08 \%, \sigma=0.14 \%$. NBS28 standard $\left(\delta^{18} \mathrm{O}=9.60 \%\right)$ gave an average values of $\delta^{18} \mathrm{O}=9.50 \%, \sigma=0.18 \%$. The full data set is provided in Online Resources 1, 2. 



Fig. 3 Backscattered electron images of the main mineral phases hosted within the low-and high-K crystal-rich enclaves. Type 1 (a) and type 2 (b) plagioclase crystals, type 1 (c) and type 2 (d) clinopyroxene, type 1 olivine (e) and biotite (f). See text for further information 


\section{Results}

\section{Bulk geochemistry}

A complete set of bulk rock major and trace element data has been presented and discussed in Forni et al. (2013), and our study does not attempt to duplicate it. Rather, we have expanded the bulk geochemical dataset by focusing our analyses on the bulk and groundmass compositions of crystal-rich enclaves (Gioncada et al. 2003, 2005; Davì et al. $2009,2010)$. Below we briefly summarize the salient points of Lipari bulk geochemistry.

- Major and trace element compositions (Fig. 4) describe a liquid line of descent with the early evolution dominated by fractionation of ferromagnesian phases (olivine and clinopyroxene) indicated by curved patterns (e.g., $\mathrm{MgO}, \mathrm{CaO}$ and Ni; Fig. 4a, c, e). Crystallization in the andesites is dominated by plagioclase, orthopyroxene, spinel, and apatite driving compositions to higher $\mathrm{SiO}_{2}$ with concurrent decreases in $\mathrm{Sr}, \mathrm{P}_{2} \mathrm{O}_{5}$ and Ti (Fig. 4f, d).

- Following a gap of $\sim 40 \mathrm{ka}$, and leaping the dacitic compositional field, Lipari rhyolites show depletions in $\mathrm{Sr}$, $\mathrm{Ba}, \mathrm{Nb}$ and $\mathrm{Rb}$ due to the crystallization of sanidine, and biotite, consistent with their appearance in the rhyolites (Fig. 4f, g). Normalized rare earth element (REE) patterns in the rhyolites reveal a marked negative $\mathrm{Eu}$ anomaly indicative of feldspar fractionation (Fig. 5).

- Crystal-rich enclaves present in the rhyolites span a range of compositions from HKCA andesites to trachyte (56-70 wt $\% \mathrm{SiO}_{2}$; Fig. 2) and are all considerably more potassic than typical Lipari magmas (Gioncada et al. 2003, 2005; Davì et al. 2010). Additionally some of the high-K enclaves are notably enriched in $\mathrm{P}_{2} \mathrm{O}_{5}$ (Fig. 4d) and a variety of trace elements including $\mathrm{Sr}, \mathrm{Ba}, \mathrm{Zr}$ (Fig. 4f-h) and $\mathrm{Pb}$ compared to typical Lipari volcanics.

\section{Mineral chemistry}

\section{Feldspar}

Plagioclase phenocrysts are ubiquitous in samples of all compositions from Lipari but dominate in the andesites. Their compositions range from bytownite to labradorite in basaltic andesites $\left(\mathrm{An}_{58-85}\right)$ and andesites $\left(\mathrm{An}_{48-83}\right)$, whereas rhyolites only contain oligoclase $\left(\mathrm{An}_{18-23}\right)$ (Online Resource 3). Sanidine phenocrysts $\left(\mathrm{Or}_{58-68}\right)$ have been recognized in the high- $\mathrm{SiO}_{2}$ andesites and rhyolites (Online Resource 3). Sr and Ba content in feldspars correlate negatively with An from the basaltic andesites to the andesites but drastically decreases, in the rhyolites.
Fig. 4 Selected major and trace element versus $\mathrm{SiO}_{2}$ variation diagrams for the Lipari volcanics and enclaves. Grey symbols indicate data from De Rosa et al. (2003); Gioncada et al. (2003); Davì et al. (2010); Forni et al. (2013); whereas coloured symbols refer to data from this study. $E E$ eruptive epoch

The plagioclase within the crystal-rich enclaves covers a wide range from bytownite to oligoclase $\left(\mathrm{An}_{21-77}\right)$ including compositions that are not represented in the other erupted rocks from Lipari (Online Resource 3). Two types of plagioclase have been recognized: type 1 is andesine to oligoclase $\left(\mathrm{An}_{21-38}\right)$, low $\mathrm{Sr},(124-687 \mathrm{ppm})$ plagioclase forming single crystals or sanidine cores (anti-rapakivi structure) within the low- $\mathrm{K}$ and high- $\mathrm{K}$ enclaves respectively (Fig. 3a); type 2 is bytownite to andesine $\left(\mathrm{An}_{41-76}\right)$, high-Sr (2816-4785 ppm) plagioclase generally forming euhedral crystals and containing cpx and melt inclusions (Fig. 3b).

$\mathrm{K}$-feldspars $\left(\mathrm{Or}_{55-67}\right)$ are present as crystals in the high$\mathrm{K}$ enclaves (Online Resource 3 ) and as microlites in the groundmass of the low-K enclaves (Gioncada et al. 2005; Davì et al. 2010). Ba content in the enclave sanidines (428$2394 \mathrm{ppm}$ ) increases towards crystal rims and is much higher than the one observed in the sanidines from the rhyolites (69-153 ppm).

\section{Pyroxene}

Clinopyroxene phenocrysts in the basaltic andesites and andesites are augitic in composition (Online Resource 3). Pigeonitic clinopyroxene and enstatitic orthopyroxene are abundant in the andesitic rocks (Online Resource 3) and are frequently overgrown by clinopyroxene rims (augite). The REE content in pyroxenes increases from the basaltic andesites to the andesites along with a progressively more negative Eu anomaly (Fig. 6).

The crystal-rich enclaves contain augitic to diopsidic clinopyroxene (Online Resource 3). Two types of crystals have been recognized: type 1 is highly resorbed (Fig. 3c), augitic in composition and shows very deep Eu anomaly (Fig. 6); type 2 is augitic to diopsidic, euhedral, oscillatory zoned and contains oxides and apatite inclusions (Fig. 3d). Type 2 clinopyroxene has higher $\mathrm{Eu} / \mathrm{Eu}^{*}$ compared to type 1 and is enriched in $\mathrm{CaO}, \mathrm{Al}_{2} \mathrm{O}_{3}, \mathrm{Sr}$ and LREE/HREE compared to type 1 and to the clinopyroxene from the basaltic andesites and andesites (Fig. 6).

\section{Olivine}

Olivine phenocrysts $\left(\mathrm{Fo}_{77-79}\right)$ are scarce in the basaltic andesites and andesites and frequently altered to iddingsite. 

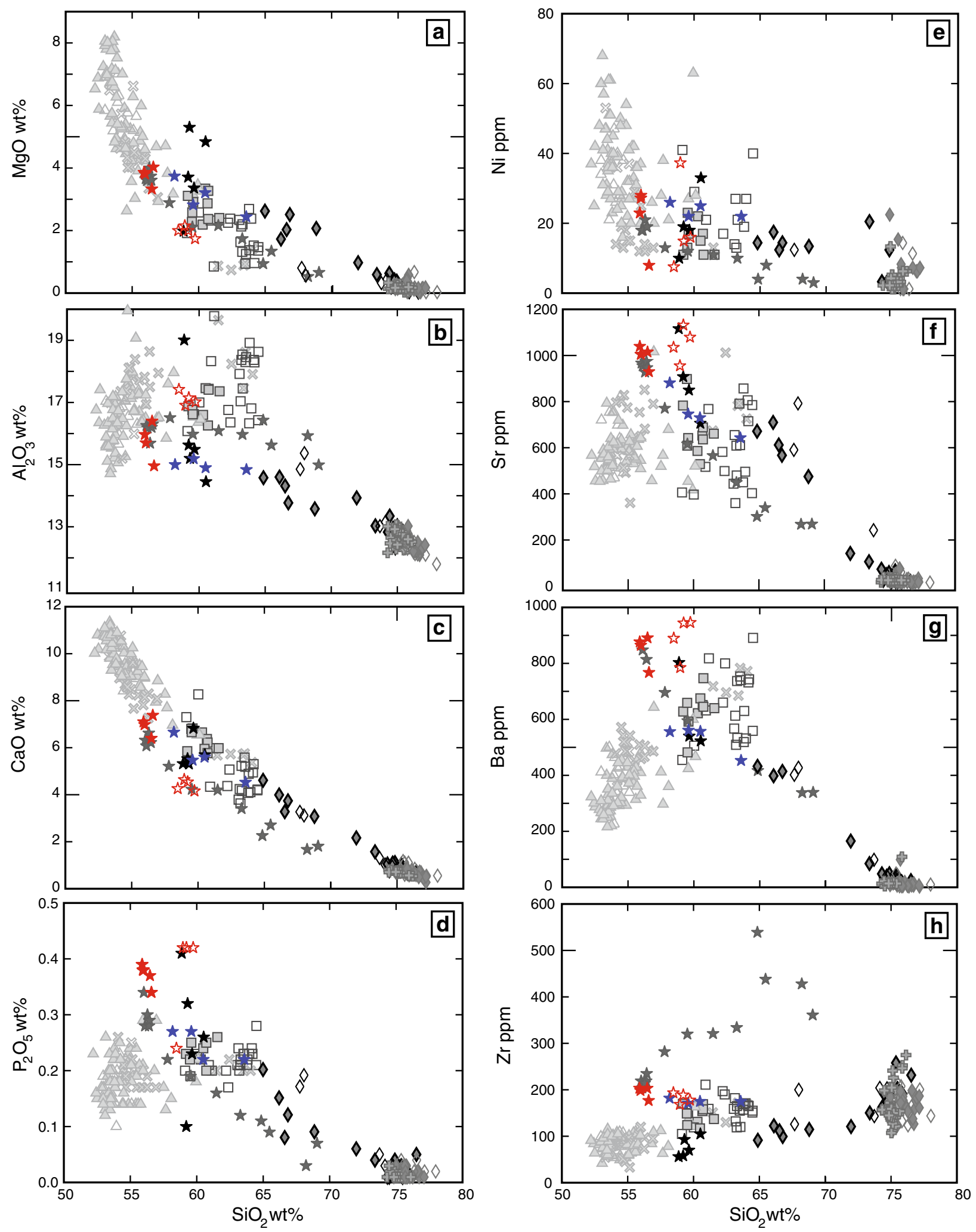

$\diamond$ EE 7 $\triangle$ EE 2 $\$ EE 4 $\square$ EE 6
$\triangle$ EE 1 $\$ EE 3 $\square$ EE5 (CBL) $\diamond$ EE 7 (mingling textures)

드 9

$\checkmark$ EE 8 (mingling textures) $\downarrow$ t EE 8 


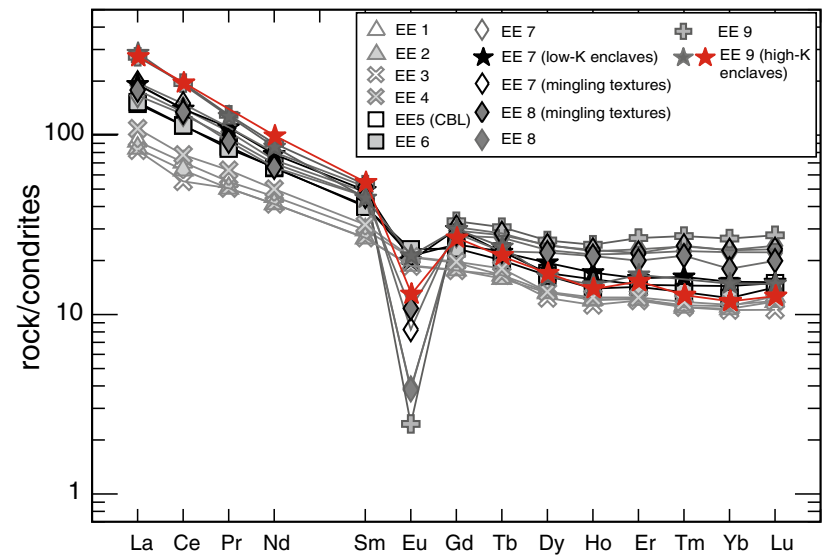

Fig. 5 Chondrite-normalized (Sun and McDonough 1989) REE patterns of Lipari volcanics and enclaves (average values for each eruptive epoch = EE). Grey symbols indicate data from De Rosa et al. (2003), Gioncada et al. (2003), Davì et al. (2010), Forni et al. (2013), whereas coloured symbols refer to data from this study

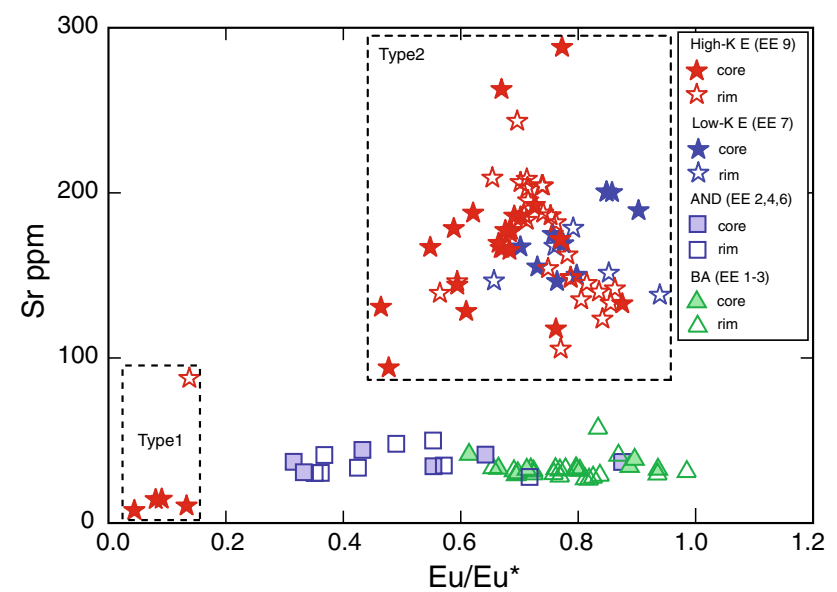

Fig. $6 \mathrm{Sr}$ versus $\mathrm{Eu} / \mathrm{Eu}^{*}$ diagram of clinopyroxenes from Lipari basaltic andesitic (BA) to andesitic (AND) volcanics and crystal-rich enclaves (E) (type 1 and type 2 clinopyroxene are distinguished; see text for further information). $E E$ eruptive epoch

In the crystal-rich enclaves, olivines occur both as partially resorbed crystals very rich in apatite inclusions, frequently forming mineral clots together with apatite and oxides (type $1 ; \mathrm{Fo}_{65-66} ; \mathrm{Ni}=131-146$ ppm; Fig. 3e) and euhedral crystals (type $2 ; \mathrm{Fo}_{74-79} ; \mathrm{Ni}=442-714 \mathrm{ppm}$ ).

\section{Biotite}

Biotite occurs as crystals (up to $0.6 \mathrm{~mm}$ ) in the high- $\mathrm{K}$ enclaves and sporadically in the rhyolites. In the enclaves, biotite phenocrysts $(\mathrm{Mg \#}=44-65)$ show normal zoning and embayed rims (Fig. 3f). Moreover they are enriched in a variety of trace elements such as Ba (up to $4866 \mathrm{ppm}$ ), $\mathrm{Nb}$ (up to $30 \mathrm{ppm}$ ) and $\mathrm{Rb}$ (up to $350 \mathrm{ppm}$ ). Tiny flakes of biotite have been recognized in the groundmass of the low-K enclaves.

\section{Fe-Ti oxides}

Ti-magnetite $\left(\mathrm{Usp}_{26-50}\right)$ occurs as microcrysts in the groundmass of basaltic andesites and as phenocrysts in the andesites, where oxides frequently form aggregates together with clinopyroxene and plagioclase. In the crystalrich enclaves, $\mathrm{Fe}-\mathrm{Ti}$ oxides ( $\mathrm{Usp}_{14-22}$ ) are abundant and occur both in the groundmass and as phenocrysts, often associated with, or included into clinopyroxene and olivine crystals (Fig. 3c-e).

\section{Crystallization temperatures}

Plagioclase cores and bulk-rock compositions, as representative of the early stage of nucleation, have been used to estimate the crystallization temperatures using the plagioclase-liquid thermometer of Putirka (2008). The equilibrium condition between mineral and melt compositions has been determined by means of test for equilibrium based on plagioclase-liquid exchange reactions (Putirka 2008). These calculations reveal that plagioclase phenocrysts within the basaltic andesites, andesites and rhyolites are mostly in equilibrium with the bulkrock (Fig. 7a). Conversely the plagioclase contained in the low-K and high-K enclaves plots predominantly out of the calculated bulk-rock equilibrium range, towards lower values of $100 \times \mathrm{Ca} /(\mathrm{Ca}+\mathrm{Na})$ (i.e. the plagioclase is more sodic than it should be based on the whole rock composition) (Fig. 7a). Plagioclase-liquid equilibrium pairs yield crystallization temperatures in the range of $\sim 1237-1077{ }^{\circ} \mathrm{C}$ for the basaltic andesites, $~ 1158-988{ }^{\circ} \mathrm{C}$ for the andesites and $\sim 884-738{ }^{\circ} \mathrm{C}$ for the rhyolites (Fig. 7b). The presence of zircons within the Lipari rhyolites allows the use of zircon saturation thermometry of Watson and Harrison (1983), which returns temperatures of $745-781{ }^{\circ} \mathrm{C}(N=38)$. It has to be noted that zircon saturation geothermometry can be applied to Lipari rhyolites since $\mathrm{U} / \mathrm{Pb}$ dating of zircon crystals indicates that they grew within the rhyolitic melt in which they are hosted, rather than being inherited from basement rocks (Poli et al. 2008). Our proposed rhyolitic temperatures are consistent with those obtained previously for Lipari rhyolites using other techniques including two feldspar thermometry (760-770 ${ }^{\circ} \mathrm{C}$, Gioncada et al. 2003), melt inclusion rehomogenisation $\left(760 \pm 10^{\circ} \mathrm{C}\right.$, De Rosa et al. 2003) and Ti-in-zircon thermometry $\left(720-800{ }^{\circ} \mathrm{C}\right.$, Poli et al. 2008) (Fig. 7b). 
Fig. 7 a Range of plagioclase composition (cores $=$ full symbols $;$ rims $=$ empty symbols) in the basaltic andesites (BA), andesites (AND), low- and high-K enclaves (E) and rhyolites (RHY) from Lipari. In the enclaves type 1 and type 2 , plagioclase are distinguished (see text for further information). Grey fields indicate the ranges of plagioclase compositions in equilibrium with the bulk-rock calculated using the $\mathrm{K}_{\mathrm{D}}(\mathrm{Ab}-\mathrm{An})=0.16-0.38$ for the BA, AND and high-K E $\left(T>1050{ }^{\circ} \mathrm{C}\right)$ and $\mathrm{K}_{\mathrm{D}}(\mathrm{Ab}-$ An) $=0.05-0.15$ for the low $-\mathrm{K}$ E and RHY $\left(T<1050^{\circ} \mathrm{C}\right)$ (Putirka 2008). b Plagioclase melt geothermometry based on Eq. 24a of Putirka (2008) for the plagioclase-liquid equilibrium pairs. Melt water contents of $1 \mathrm{wt} \%$ (BA), $2 \mathrm{wt} \%$ (A and E) and $3 \mathrm{wt} \%$ (RHY) were used in the thermometric calculations. It has to be noted that the estimated temperatures obtained by changing the melt water content by $1 \%$ are included within the error. Temperature ranges obtained for the Lipari rhyolites using other methods are shown for comparison
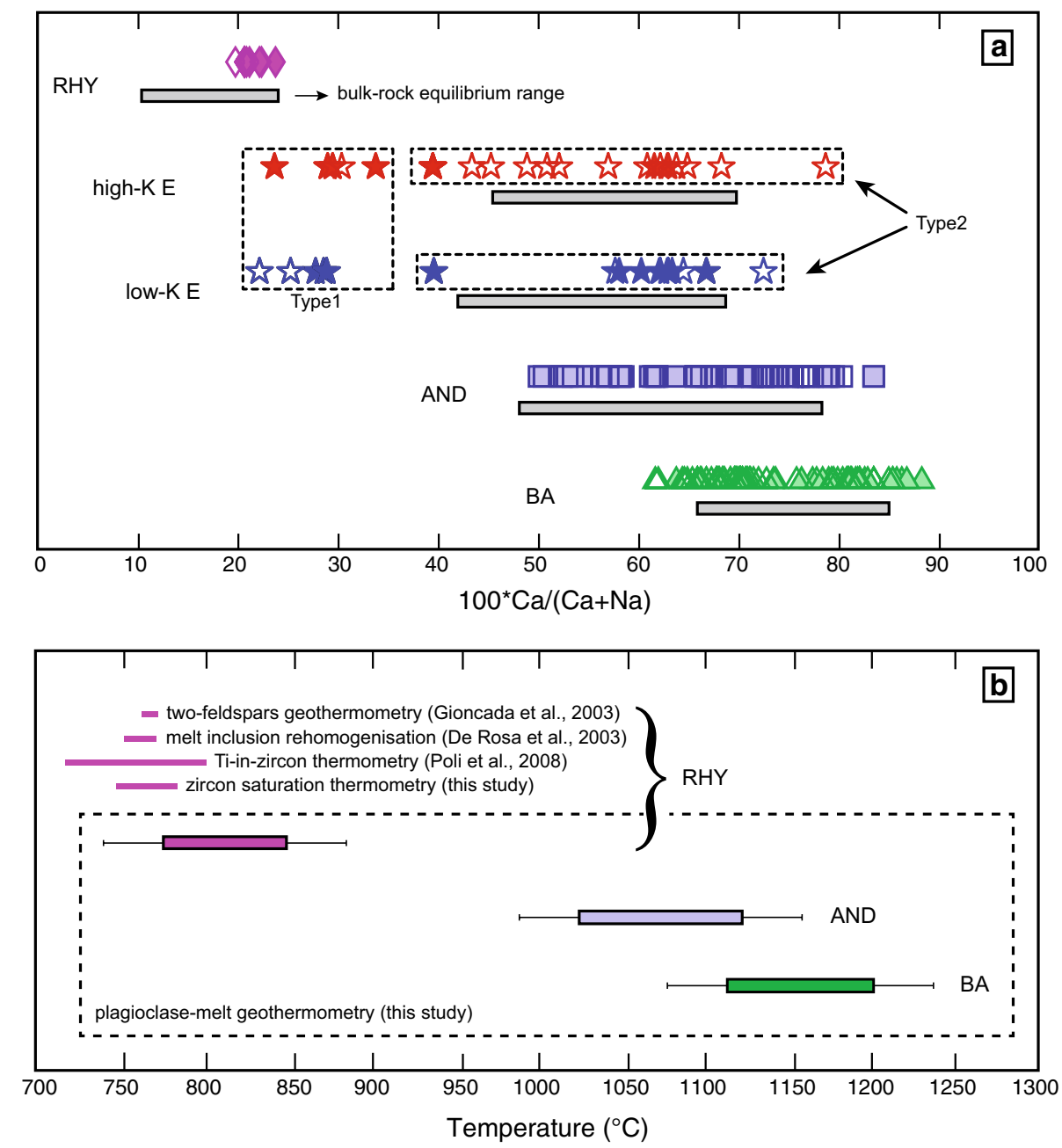

\section{Isotope geochemistry}

\section{Radiogenic isotopes ( $\mathrm{Sr}, \mathrm{Nd}$ and $\mathrm{Pb}$ )}

$\mathrm{Sr}$ and $\mathrm{Nd}$ isotope ratios of Lipari magmas range from 0.70442 to 0.70578 and from 0.51251 to 0.51271 , respectively, partially overlapping with the isotopic data from the literature and the isotopic compositions of all the other Aeolian Islands, except for Alicudi, which has the most primitive isotopic compositions of the whole arc (Peccerillo et al. 2004) (Fig. 8a). The basaltic andesites of EE 2 cover almost the entire range of isotopic compositions. ${ }^{87} \mathrm{Sr} /{ }^{86} \mathrm{Sr}$ and ${ }^{144} \mathrm{Nd} /{ }^{143} \mathrm{Nd}$ ratios increase and decrease, respectively, with $\mathrm{SiO}_{2}$ from the basaltic andesites to the andesites (EE 1-6), but remain fairly constant from the andesites to the rhyolites (EE 7-9) (Online Resource 4). The highest $\mathrm{Sr}$ and lowest $\mathrm{Nd}$ isotopic ratios are reported for the cordierite-bearing lavas (EE 5) and one sample from EE 2, which contains granulitic xenoliths. In the petrogenesis of the cordierite-bearing lavas, a large involvement of a crustal component is supported by the $\mathrm{Sr}$ and
$\mathrm{Nd}$ isotopic composition of cordierite $(\mathrm{Sr}=0.71023$ and $\mathrm{Nd}=0.51200$ ), which plots within the field of the granulitic and metapelitic rocks of the Calabro-Peloritano basement (Di Martino et al., 2011) (Fig. 8a). Pb isotope ratios span narrow ranges $\left({ }^{206} \mathrm{~Pb} /{ }^{204} \mathrm{~Pb}=18.273-19.556\right.$; ${ }^{207} \mathrm{~Pb} /{ }^{204} \mathrm{~Pb}=15.655-15.725 ;{ }^{208} \mathrm{~Pb} /{ }^{204} \mathrm{~Pb}=38.318-$ 40.047; Online Resource 1).

\section{Stable isotopes $(\mathrm{O})$}

Oxygen isotopes from minerals on Lipari span a wide range in $\delta^{18} \mathrm{O}$ from $6.2 \%$ for an olivine in a basaltic andesite to $14.4 \%$ for a garnet from one of the cordierite-bearing andesites (Fig. 8c). Oxygen isotopic compositions of euhedral clinopyroxene phenocrysts, which occur throughout the magmatic series on Lipari, vary in $\delta^{18} \mathrm{O}$ from 6.3 to $7.9 \%$. Olivine phenocrysts within the basaltic andesites and andesites return $\delta^{18} \mathrm{O}$ values of 6.2 and $6.8 \%$ indicating high temperature $\mathrm{O}$ isotopic equilibrium with the coexisting clinopyroxene $(\Delta \mathrm{cpx}-\mathrm{ol}=0.5 \%$ Valley et al. 2003). Cordierite and garnet within the cordierite-bearing 

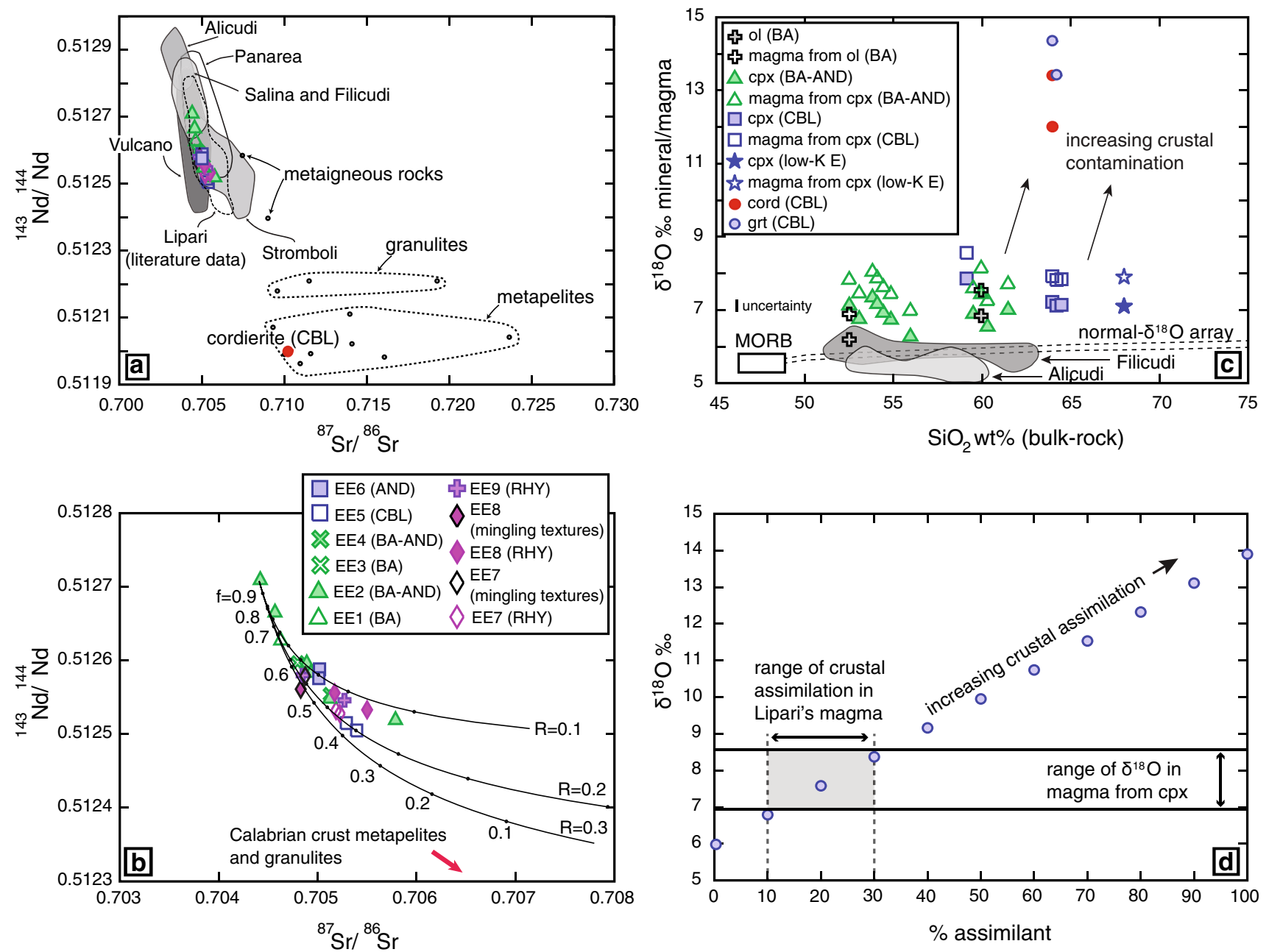

Fig. 8 a $\mathrm{Nd}$ versus $\mathrm{Sr}$ isotope ratios of Lipari volcanics ( $B A$ basaltic andesites, $A N D$ andesites, $C B L$ cordierite-bearing lavas and $R H Y$ rhyolites) compared to the literature isotope data of Lipari and the other Aeolian Islands (data from De Astis et al. 2013; Forni et al. 2013; Francalanci et al. 2013; Lucchi et al. 2013a, b, c, d). The isotopic composition of the main lithologies of the Calabrian Basement (data from Caggianelli et al. 1991) and the cordierite from the CBL (from Di Martino et al. 2011) are shown as representative of the crustal rock compositions. b AFC geochemical modelling obtained for different assimilation/fractional crystallization ratios (R). Tick marks and numbers along the lines refer to the liquid fraction (f). Analytical uncertainties are smaller than symbol sizes. $E E$ eruptive epoch.

lavas return very high $\delta^{18} \mathrm{O}$ (13.4 and $14.4 \%$, respectively) indicative of the presence of a high- $\delta^{18} \mathrm{O}$ crustal component in the region. Assuming a cpx-melt fractionation of $0.7 \%$ o (diopside-andesitic melt at $1050{ }^{\circ} \mathrm{C}$; Valley et al. 2003), the calculated oxygen isotope composition of the equilibrium melts $\left(\delta^{18} \mathrm{O}=7-8.6 \%\right)$ is higher than the ranges obtained by closed-system fractional crystallization of mantle-equilibrated melts and the calculated oxygen isotope compositions of equilibrium melts from Alicudi and Filicudi (Peccerillo et al. 2004; Santo and Peccerillo 2008) (Fig. 8c).

c $\delta^{18} \mathrm{O}$ of minerals (ol olivine; cpx clinopyroxene; cord cordierite; grt garnet) and calculated equilibrium melt versus $\mathrm{SiO}_{2}$ variations in Lipari volcanics and enclaves (E). Oxygen isotope compositions of melts in equilibrium with clinopyroxene from Alicudi and Filicudi as representative of primitive isotopic compositions are reported for comparison (Santo and Peccerillo 2008; Peccerillo et al. 2013). d Simple bulk-mixing model showing the amount of crustal component to be added to a primitive magma $\left(\delta^{18} \mathrm{O}=6 \%\right.$ ) to match the range of oxygen isotope compositions observed in Lipari volcanics. $\delta^{18} \mathrm{O}$ of the crustal component has been estimated based on the oxygen isotope compositions of cordierite and garnet from the CBL. See text for further information

Calculated melt oxygen isotope compositions show weak correlation with bulk-rock $\mathrm{SiO}_{2}$ (Fig. 8c) and positive correlation with ${ }^{87} \mathrm{Sr} /{ }^{86} \mathrm{Sr}$.

\section{Geochemical modelling}

In order to account for the generation of the whole compositional range observed for the Lipari magmas, geochemical models based on major element and isotopic 
compositions have been tested. The sample LIP 105 (EE 2) has been chosen as parent in the models because of its primitive geochemical and isotopic signatures $\left(\mathrm{Ni}=68 \mathrm{ppm} ; \mathrm{Cr}=170 \mathrm{ppm} ;{ }^{87} \mathrm{Sr} /{ }^{86} \mathrm{Sr}=0.70442\right.$; $\left.{ }^{143} \mathrm{Nd} /{ }^{144} \mathrm{Nd}=0.51271\right)$. According to the inferred nature of the basement rocks (Ventura et al. 1999; Peccerillo et al. 2006; Di Martino et al. 2011; Ventura 2013) and depth of magma storage (De Rosa et al. 2003; Di Martino et al. 2010), the average bulk-rock and isotopic composition of the metapelites and granulites from the Calabrian Basement (Caggianelli et al. 1991) has been considered as representative of the crustal contaminant. Least-square mass balance calculations have been carried out in two stages (step 1, from basaltic andesites to andesites; step 2, from andesites to rhyolites, Online Resource 5) using the OPTIMASBA code (Cabero et al. 2012) in order to account for the major changes in the crystallizing mineral assemblage occurring during magmatic evolution. Accordingly, average mineral and bulk-rock (i.e. parent and daughter magmas and contaminant) compositions have been used as input data in the model. The software calculates the relative proportions of crystallizing mineral phases producing the best fit between the simulated and the real derivative magma composition. During step 1, crystallization of predominant Ca-rich plagioclase and pyroxenes with small amounts of olivine, Fe-Ti oxides and apatite, coupled with $\sim 20 \%$ crustal assimilation, drives the liquid from basaltic andesitic to andesitic compositions (Online Resource 5). During step 2, plagioclase, clinopyroxene, biotite, $\mathrm{Fe}-\mathrm{Ti}$ oxides, sanidine, olivine and apatite are the main crystallizing phases and smaller amounts of crustal contamination $(\sim 2 \%)$ are required to match the high- $\mathrm{SiO}_{2}$ rhyolite daughter composition (Online Resource 5).

Further constraints can be placed on the degree of crustal assimilation required via $\mathrm{AFC}$ and mixing modelling using of the radiogenic and stable isotope data. The partition coefficients of $\mathrm{Sr}$ and $\mathrm{Nd}$ used in the AFC models (1.5 and 0.5 , respectively) have been estimated according to Rollinson (1993) based on the relative proportions of crystallizing phases. AFC models show that the whole range of isotopic compositions displayed by the Lipari magmas can be obtained by assimilation/fractional crystallization ratios $(R)$ between 0.1 and 0.3 (Fig. 8b). Unlike the $\mathrm{Sr}$ and $\mathrm{Nd}$ radiogenic isotope ratios, the $\mathrm{O}$ isotopic composition of the Calabrian Basement remains unknown. However, we can approximate it via use of the compositions of the cordieritebearing lavas from EE 5. Both garnet-liquid and cordieriteliquid fractionation factors are poorly known; however, given that globally siliciclastic metamorphic rocks span the range of 4-21\%o (Bindeman 2008), using an average of the two measured values (13.4 and $14.4 \%$ o) seems a reasonable estimate. At high temperatures, $\Delta(\mathrm{Gt}-\mathrm{zrc})=0.0 \pm 0.2 \%$ o (Valley et al. 1994) and $\delta^{18} \mathrm{O}$ of zircon is typically a few per mil lower than the co-existing melt (Bindeman 2008), so our inference of a crustal end-member of $\delta^{18} \mathrm{O}=13.9 \%$ o might err on the side of over-estimating the proportion of assimilant required. Bearing this in mind, we can use mixing models to estimate how much of that component would be required to elevate the $\delta^{18} \mathrm{O}$ of the magmas from a purely fractionation-derived value to the observed compositions (Fig. 8d). These simple bulk-mixing models confirm that between approximately 10 and $30 \%$ of the assumed crustal end-member would be required in petrogenesis. These values are in excellent agreement with those determined via mass balance modelling and radiogenic isotopic compositions above.

\section{Discussion}

\section{Genesis of Lipari rhyolites}

The occurrence of rhyolites during the most recent volcanism on Lipari (43 ka-AD 1220) and the presence of both a temporal and compositional gap prior to their appearance bear on how the rhyolites are made. A main role for crustal melting in the genesis of the rhyolites was invoked in the early studies of Crisci et al. (1991) and Esperanca et al. (1992), mainly supported by evidences of magmawall rock interactions in some of the magmatic rocks older than 43-40 ka (in particular in the cordierite-bearing lavas; Barker 1987; Di Martino et al. 2011). However, in contrast to the cordierite-bearing lavas, the geochemical and isotopic signature of Lipari rhyolites strongly indicates that they were generated via fractional crystallization of mantle-derived melts coupled with minor amounts of crustal contamination (Gioncada et al. 2003; Davì et al. 2010; this study). Based on the geochemical similarities between the rhyolites from Lipari and Vulcano and a similar influence of the regional tectonic setting on the volcanism of the two islands, Gioncada et al. (2003) and Davì et al. (2010) hypothesized that the two volcanic islands have shared the same plumbing system and magmatic evolution, at least during the last $\sim 40 \mathrm{ka}$. In particular, the high- $\mathrm{SiO}_{2}$ magmas on both islands have been deemed to derive via AFC from shoshonitic melts akin to the ones preserved as melt inclusions within some primitive olivine crystals at Vulcano (Gioncada et al. 1998; Davì et al. 2010). Such a scenario would be also supported by the finding of latitic enclaves within the rhyolites from Lipari, representing the intermediate products of this fractional crystallization path (Davì et al. 2009). Although we cannot exclude the existence of a connection between the plumbing systems of Lipari and Vulcano, such a connection appears unlikely for the shallow subvolcanic reservoirs (5-10 $\mathrm{km}$ depth range). Therefore we explore the possibility that the rhyolites from 
Lipari were derived, independently from those at Vulcano, via AFC from the intermediate compositions, with crystalmelt mechanics controlling the compositional gap (Dufek and Bachmann 2010).

The decrease in trace elements compatible into early crystallising phases (e.g., Ni, Cr; Fig. 4e) and the curved paths of elements which change the compatibility during differentiation (e.g., Sr, Ba, $\mathrm{P}$ as phases such as biotite, sanidine, plagioclase and apatite start crystallizing; Fig. 4d, f, g) strongly suggests that crystal fractionation is playing a key role throughout petrogenesis (Wade et al. 2005; Deering and Bachmann 2010; Lee and Bachmann 2014). This interpretation is supported by the marked negative Eu anomaly observed in the rhyolites (Fig. 5), which is indicative of feldspar fractionation. Both the radiogenic and stable isotopes of Lipari volcanics indicate that assimilation of crustal material undoubtedly plays a role in petrogenesis especially during the evolution from the mafic to the intermediate compositions, where the proportion of crustal material involved is up to $30 \%$, but considerably decreases during the late stages, which led to the genesis of the rhyolitic melts (Online Resource 4). The positive correlations between oxygen and $\mathrm{Sr}$ isotopic ratios also support magma evolution dominated by AFC processes (fractional crystallization coupled with crustal assimilation; Francis et al. 1980; Taylor 1980).

Mass balance calculations indicate that rhyolitic melts can be derived from the intermediate compositions via AFC processes after $\sim 60 \%$ crystallization, coupled with $\sim 2 \%$ crustal assimilation (Online Resource 5). Decreasing crustal contamination with ongoing magma evolution has been observed in a variety of magmatic suites (e.g., Cox and Devey 1987; Kerr et al. 1995; Peccerillo et al. 2004; Deering et al. 2011a) and is interpreted as the result of a less efficient magma-wall rocks interaction due to temperature drop and increase of magma viscosity as reservoirs are stored in relatively cold upper crust (see Depaolo 1981; Thompson et al. 2002; Dufek and Bergantz 2005).

Such a fractionation-dominated origin reflects a compositional evolution along a dominantly down-temperature trend and yields relatively low-temperature silicic endproducts. The suggestion that Lipari rhyolites have been "superheated" (Davì et al. 2010, 2011) appears untenable as magmatic temperatures are relatively low, as indicated by different geothermometers returning typical rhyolitic temperatures (Fig. 7b). Moreover, crystals in equilibrium with the rhyolitic melt can be found within the Rocche Rosse lava flow (Gioncada et al. 2003, 2005; Davì et al. 2009, 2010). In particular, the presence of biotite in some of the rhyolites further suggests that temperatures were not unusually high.

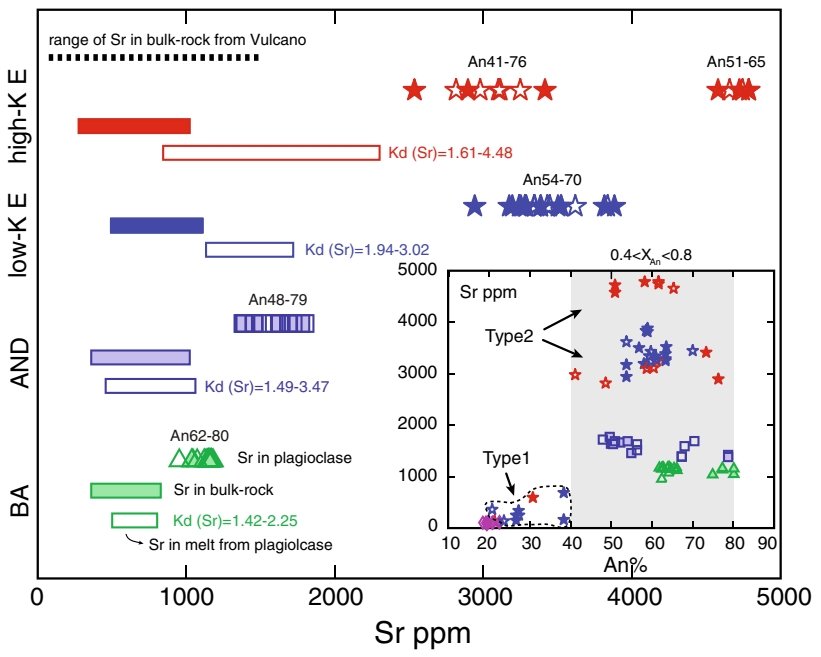

Fig. 9 Range of Sr contents in plagioclase (cores = full symbols; rims $=$ empty symbols) and bulk-rock (full bars) basaltic andesites (BA), andesites (AND), low- and high-K enclaves (E) from Lipari. Calculated $\mathrm{Sr}$ content in the melt in equilibrium with the plagioclases (empty bars) and plagioclase/melt partition coefficients $(\mathrm{Kd}(\mathrm{Sr})$ ) have been obtained using the equation of Bindeman et al. (1998) within the range of $0.4<X_{\mathrm{An}}<0.8$ of plagioclase compositions. $\mathrm{Sr}$ versus An $\%$ variations in plagioclases are shown in the inset (in the enclaves type 1 and type 2 plagioclase are distinguished; see text for further information)

\section{Origin of crystal-rich enclaves on Lipari}

The crystal-rich enclaves in the rhyolitic products of Lipari (EE 7-9) fall notably off the overall evolutionary trend described by Lipari magmas, showing enrichment in $\mathrm{Sr}$, $\mathrm{Ba}, \mathrm{Zr}, \mathrm{K}_{2} \mathrm{O}$ and $\mathrm{P}_{2} \mathrm{O}_{5}$ compared to the other Lipari volcanics (Figs. 2, 4). This geochemical characteristic was considered to be the result of the involvement of multiple magmas in the petrogenesis (Gioncada et al. 2003, 2005; Davì et al. 2009, 2010). In such a scenario, the enclaves were attributed to more alkaline magmas from the Vulcano suite, which mingled and co-erupted with magmas underneath Lipari. Volumetrically, the proportion of enclaves within the rhyolitic host magma is small, typically less than $1 \%$ of the material erupted in the case of the Rocche Rosse lava flow (Davì et al. 2010). If the alkaline magma from Vulcano is present as a liquid in the upper crust beneath Lipari, the question of why more Vulcano-type magmas have not erupted from Lipari is hard to explain. This would also require that the subvolcanic reservoirs are linked, something unknown anywhere on Earth for such small arc volcanoes. Perhaps even more problematic for the Vulcano-Lipari connection is that while the Lipari crystalrich enclaves compositionally resemble the alkaline magmas erupted on nearby Vulcano, a number of lines of evidence (including the presence of zircons in such alkaline magmas) suggest that their compositions do not reflect true 
magmatic liquids. In the following sections we explore the possibility that the crystal populations within the enclaves provide clues as to their origin.

\section{Plagioclase}

Simple partitioning calculations demonstrate that neither of the two types of crystals present in the enclaves (Fig. 3a,b) are in equilibrium with the bulk-rock. Indeed, the low An $\left(\mathrm{An}_{21-38}\right)$ and $\mathrm{Sr}$ content (124-687 ppm) in type 1 plagioclase are indicative of crystallization from a liquid compositionally more evolved than the bulk-rock (Figs. 7a, 9). Additionally, textural features indicate that type 1 plagioclase was partially resorbed and subsequently encountered a $\mathrm{K}_{2} \mathrm{O}$ and Ba-rich melt from which the high-Ba sanidine rims grew (Fig. 3a). On the contrary, the euhedral type 2 plagioclase $(\mathrm{Sr}=2816-4785 \mathrm{ppm})$ rather crystallized from a Srrich melt (Figs. 3b, 9). The amount of $\mathrm{Sr}$ in the melt required to generate type 2 plagioclases (836-2324 ppm), calculated using the experimentally derived equation of Bindeman et al. (1998), is much higher than the actual Sr content in the bulkrock enclaves (262-1116 ppm) and even in all the magmatic rocks from Vulcano (50-1532 ppm; Fig. 9). Additionally, the lack of correlation between $\mathrm{Sr}$ and An content suggests that crystallization of type 2 plagioclase occurred under disequilibrium conditions (Blundy and Wood 1991).

\section{Other minerals}

- Similarly to plagioclase, highly resorbed type 1 clinopyroxene shows low $\mathrm{Sr}$ content (8-88 ppm, increasing towards the rim) and deep negative Eu anomaly $\left(\mathrm{Eu} / \mathrm{Eu}^{*}=0-0.1\right)$ indicative of crystallization from an evolved melt, which underwent intense feldspar fractionation (Fig. 6), while major and trace element composition of type 2 euhedral clinopyroxene $(\mathrm{Sr}=94-278 \mathrm{ppm} ; \mathrm{Eu} /$ $\left.\mathrm{Eu}^{*}=0.5-0.9\right)$ instead suggest that it crystallized from a $\mathrm{Sr}, \mathrm{CaO}, \mathrm{Al}_{2} \mathrm{O}_{3}$ and LREE-rich melt (Fig. 6).

- Type $1\left(\mathrm{Fo}_{65-66} ; \mathrm{Ni}=131-146 \mathrm{ppm}\right)$ and type $2\left(\mathrm{Fo}_{74-}\right.$ ${ }_{79} ; \mathrm{Ni}=442-714 \mathrm{ppm}$ ) olivine crystals coexist within the crystal-rich enclaves. The occurrence of high-Fo euhedral olivine crystals suggests involvement of fresh mafic magma, whereas mineral aggregates containing low-Fo olivine (and abundant apatite, Fig. 3e) indicate accumulation of crystals under relatively reducing redox conditions and high $\mathrm{H}_{2} \mathrm{O}$ content at relatively shallow depth (Berndt et al. 2005; Portnyagin et al. 2012). Removal of $\sim 0.5 \%$ apatite during the fractionation step leading to the rhyolite formation (Online Resource 5) is enough to account for the significant drop of $\mathrm{P}_{2} \mathrm{O}_{5}$ in the bulk-rock (Fig. 4d).

- Biotite only occurs as individual crystals showing embayed rims (Fig. 3f) within the high-K enclaves.
Trace element compositions of biotite crystals are compatible with crystallization from a dacitic/rhyolitic melt, given the relatively high biotite/melt partition coefficients of $\mathrm{Ba}, \mathrm{Rb}$ and $\mathrm{Nb}$ in these magmas (Rollinson 1993).

- Zircon crystals occur in some of the crystal-rich enclaves (Gioncada et al. 2005; Davì et al. 2009). Given the very low saturation temperature of zircon in $\mathrm{K}_{2} \mathrm{O}$-rich magmas (Watson and Harrison 1983), zircon crystallization is a strong argument against the crystal-rich enclaves representing clasts from alkaline melt.

\section{The role of cumulates in rhyolite petrogenesis}

The textural and compositional features of type 1 crystals (plagioclase, clinopyroxene and olivine) and biotite indicate that they might represent mineral phases which crystallized from an intermediate to evolved melt (i.e. dacite/rhyolite) during the fractionation step leading to the generation of the high- $\mathrm{SiO}_{2}$ rhyolites. As discussed above, we infer that high- $\mathrm{SiO}_{2}$ melts were produced via fractional crystallization, which requires a residue of crystals to accumulate somewhere in the crust. Extraction of $\mathrm{SiO}_{2}$-rich melts from the crystal-rich cumulates has been rarely considered due to the high viscosity and low permeability conditions which would prevent crystal/melt segregation to generate large rhyolitic magmas bodies on geologically reasonable timescales (see Mckenzie 1985; Eichelberger et al. 2006). However, it has been demonstrated that crystal-liquid separation can be very efficient at intermediate crystallinity (50-70 \% crystals; Bachmann and Bergantz 2004) when convection in the magma chamber has stopped and permeability is still high enough for the expulsion of crystalpoor melts from the crystalline mush zone (Bachmann and Bergantz 2004; Dufek and Bachmann 2010). Experimental studies have shown that the presence of volatiles, as well as a local increase of the shear rate, can have important effects on reducing the viscosity of $\mathrm{SiO}_{2}$-rich magmas thus favouring distillation of interstitial liquids from their cumulates along interconnected porous networks (e.g., Caricchi et al. 2007; Pistone et al. 2015).

In order to test the potential link between the crystal-rich enclaves and the crystal-poor rhyolites, we used trace element geochemical modelling based on the equations for the conservation of mass of a fractionating trace element (see Gelman et al. 2014 for a recent discussion on the derivation of these equations). The trace elements used in the models are the ones with the best known partition coefficients, the best know geochemical behaviours, and abundant enough that they can be accurately measured. We used the modal proportions of fractionating phases derived from the mass balance calculations to estimate the bulk-rock partition coefficients because they closely match the mineral 
assemblage that have been observed in most crystal-rich enclaves (Gioncada et al. 2005). Two different starting compositions were chosen, in order to bracket a range of initial trace element concentrations plotting between the enclaves, showing evidence of crystal accumulation, and the crystalpoor rhyolites. We assume that the starting compositions plot within the compositional gap (i.e., dacitic field; Fig. 2) because this likely corresponds to the intermediate liquid composition parental to the rhyolite, and not impacted by crystal accumulation. Although these compositions are not represented in the erupted products of Lipari (as one would expect if the crystal-liquid separation is efficient, producing rhyolite and left-over cumulate), the presence of $\mathrm{An}_{38-21}$ plagioclase crystals in the enclaves (type 1; Online Resource 3) strongly suggests initial crystallization from a dacitic magma. We tested the model using the two different starting compositions and a range of partition coefficients from Nash and Crecraft (1985) and Rollinson (1993) (see Online Resource 6). Additionally, according to the results of mass balance calculations and isotope geochemical modelling, small amounts of crustal contamination (i.e. $2 \%$ ) were added to the system. When using the high partition coefficients (typical for silicic magmas), $\mathrm{Sr}, \mathrm{Ba}$ and $\mathrm{Rb}$ concentrations predicted by the model for extracted liquids and cumulates match well the crystal-rich enclaves and rhyolites across a range of melt fractions (Fig. 10). The same results were obtained using a variety of trace elements $(\mathrm{Eu}, \mathrm{Sc}, \mathrm{Cr}$ and $\mathrm{Co}$ ), which show compatible behaviour with respect to the most abundant crystallizing phases (feldspars, clinopyroxene and oxydes; Online Resource 7). Some of the scatter displayed by a few samples is induced by mixing/mingling textures (frequently observed in some of the rhyolites; De Rosa et al. 2003), and plot on straight-line trajectories (i.e. mixing lines) connecting the rhyolites and the crystal-rich enclaves compositions (Fig. 10 and Online Resource 7).

The occurrence of euhedral crystals (type 2 mineral phases) showing particularly enriched compositions and coexisting with type 1 crystals within the enclaves, suggests the participation of locally enriched melts in petrogenesis. In particular, the presence of relatively primitive olivine crystals (type 2), akin to ones from Lipari basaltic andesites, indicates crystallization from a mafic magma. Indeed, mafic recharge is required to provide the heat necessary to remobilize the cumulate material (which is likely uneruptible with crystallinities $>50 \%$ when unmelted) by lowering its crystallinity via thermal remobilization (Deering et al. 2011b; Wolff et al. 2015). This process, preferentially affecting the relatively low-temperature crystallizing phases (feldspars and biotite), might have promoted the generation of melts (potentially interacting with the recharge magma) locally enriched in $\mathrm{Sr}, \mathrm{Ba}, \mathrm{K}_{2} \mathrm{O}, \mathrm{CaO}, \mathrm{Al}_{2} \mathrm{O}_{3}$ and LREE, from which type 2 plagioclase and clinopyroxene and Ba-rich sanidines crystallized under disequilibrium conditions. Such

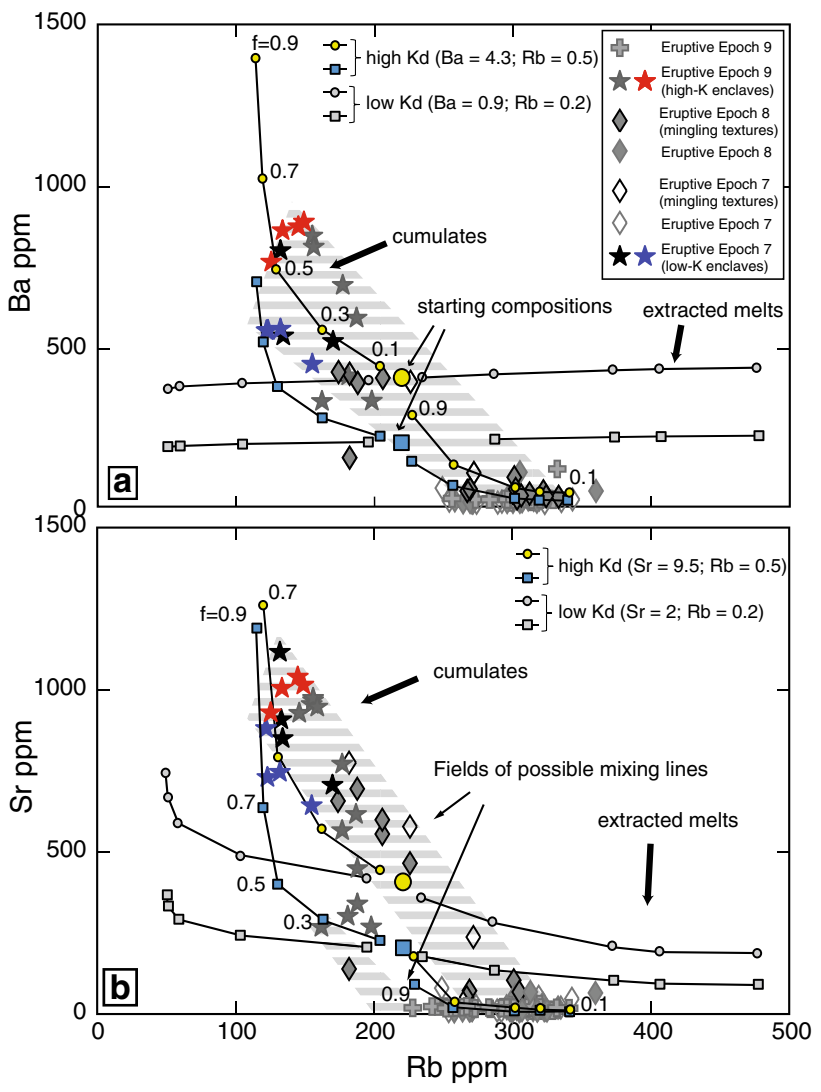

Fig. 10 Trace element modelling obtained using $\mathrm{Rb}$ versus $\mathrm{Ba}(\mathbf{a})$ and $\mathrm{Rb}$ versus $\mathrm{Sr}(\mathbf{b})$ diagrams. Symbols and numbers along the lines indicate melt fraction (f). Starting compositions have been considered to plot within the compositional gap (see text for further information). Partition coefficients have been estimated based on the mineral proportions obtained from mass balance calculations. High and low partition coefficients have been tested (see Online Resource 6). Grey symbols indicate data from De Rosa et al. (2003), Gioncada et al. (2003), Davì et al. (2010), Forni et al. (2013), whereas coloured symbols refer to data from this study

a scenario would explain the coexistence within the crystalrich enclaves of texturally and compositionally different mineral phases, showing clear evidence of disequilibrium. An alternative interpretation is that all the type 2 mineral phases may have been carried by the recharge magma rather than crystallizing from a mush-derived melt. Although we cannot exclude this possibility, we consider it extremely unlikely due to the very high $\mathrm{Sr}$ content in type 2 plagioclases, which excludes crystallization from melts akin to any of the magmas erupted on Lipari and Vulcano.

\section{Crystal-rich enclaves on Vulcano}

Crystal-rich enclaves $(\sim 20-30 \%$ crystals), showing the same composition and mineral assemblage of Lipari high$\mathrm{K}$ enclaves and containing Sr-rich plagioclases, have been recognized within the Pietre Cotte rhyolitic lava flow on 
Vulcano (Perugini et al. 2007; Piochi et al. 2009). Similarly to what has been suggested for Lipari (Gioncada et al. 2005; Davì et al. 2009), the Pietre Cotte enclaves have been considered to represent a latitic to trachytic magma interacting with a crystal-poor rhyolitic melt and being co-erupted (Perugini et al. 2007; Piochi et al. 2009). However, crystallization of such Sr-rich plagioclases (4406-5233 ppm; Piochi et al. 2009) from latitic to trachytic magma would require extremely high plagioclase/ melt partition coefficients for $\mathrm{Sr}$ or extremely high $\mathrm{Sr}$ contents in the melt. Notably, the Sr plagioclase/melt partition coefficient calculated for the Pietre Cotte enclaves (9.92; Piochi et al. 2009) is significantly higher than the partition coefficient reported in the literature for latitic (1.3; Villemant 1988) and trachytic melts (0.94-6.6; Nagasawa 1973; Villemant 1988). Hence, we suggest that such enclaves in Vulcano are also remobilized cumulates, as have been reported from other locations (Crater lake, Bacon and Druitt 1988; Ammonia Tanks Tuff, Deering et al. 2011b; Carpenter Ridge Tuff, Bachmann et al. 2014; Snake River Plain, Ellis et al. 2014).

\section{Concluding remarks}

Following a hiatus of $\sim 40 \mathrm{ky}$, the youngest eruptive epoch of Lipari is characterized by the appearance of crystal-poor rhyolites (43 ka-AD 1220; Gioncada et al. 2003; Forni et al. 2013). The eruption of rhyolites acts to bookend a compositional suite of rocks characterized by a marked lack of dacitic compositions. The mineralogy, geochemistry and isotopic ratios all support fractional crystallization with limited assimilation of crustal material as the main drive behind the generation of the calc-alkaline rhyolites of Lipari. Such a conclusion is particularly well illustrated in Lipari, as one can compare such AFC-derived silicic magmas with others clearly involving high crustal components (Di Martino et al. 2011). As expected on thermal grounds (e.g., Thompson et al. 2002), the majority of the crustal assimilation occurs during the early stages of petrogenesis with relatively steep increases in isotopic crustal tracers within the basaltic andesites and andesites and then little further increase from andesites to rhyolites.

Together, the crystal-poor nature and low eruptive temperatures of the Lipari rhyolites imply efficient crystal-melt separation in upper crustal mush zones. The presence of crystal-rich enclaves with cumulate signatures in the rhyolites directly provides the complementary crystal residues. Mass balance modelling indicates that such rhyolites can be generated by extraction of interstitial melts from originally intermediate compositions after $\sim 60 \%$ crystallization. These results are in agreement with fluid dynamics models, which suggest crystallinities of 50-70\% crystals as the most suitable window for melt extraction and generation of compositional gaps (Dufek and Bachmann 2010). Such an association between crystal-poor rhyolites and crystal-rich, remobilized cumulates is increasingly recognized in many places around the world (e.g., Bachmann and Bergantz 2004; Shane et al. 2005; Bacon et al. 2007; Lipman 2007; Deering et al. 2011b, c; Ellis et al. 2014; Wolff et al. 2015) and strongly argues for the ubiquity of the process.

Acknowledgments We would like to thank Duncan Muir and Marcel Guillong for their precious assistance during the microprobe and laser analyses and Nicola Costa for helping during sample preparation. We express our gratitude to George Cooper and an anonymous referee for constructive reviews and to Othmar Müntener for the most appreciated editorial effort he invested in this paper. This work has been supported by Swiss National Science Foundation grant 200021_146268 to Olivier Bachmann, CARG (Geological mapping of Italy-scale 1:50.000, sheets Nos. 577 bis, 580 bis and 581/586) and RFO (research founds of the University of Bologna) grants.

\section{References}

Bachl CA, Miller CF, Miller JS, Faulds JE (2001) Construction of a pluton: evidence from an exposed cross section of the Searchlight pluton, Eldorado Mountains, Nevada. Geol Soc Am Bull 113(9):12131228. doi:10.1130/0016-7606(2001)113<1213:Coapef $>2.0$.Co;2

Bachmann O, Bergantz GW (2004) On the origin of crystal-poor rhyolites: extracted from batholithic crystal mushes. J Petrol 45(8):1565-1582. doi:10.1093/Petrology/Egh019

Bachmann O, Bergantz GW (2008) Rhyolites and their source mushes across tectonic settings. J Petrol 49(12):2277-2285. doi:10.1093/Petrology/Egn068

Bachmann O, Deering CD, Lipman PW, Plummer C (2014) Building zoned ignimbrites by recycling silicic cumulates: insight from the $1,000 \mathrm{~km}^{3}$ Carpenter Ridge Tuff, CO. Contrib Mineral Petrol. doi:10.1007/S00410-014-1025-3

Bacon CR, Druitt TH (1988) Compositional evolution of the zoned calcalkaline magma chamber of Mount Mazama, Crater Lake, Oregon. Contrib Mineral Petrol 98(2):224-256. doi:10.1007/ BF00402114

Bacon CR, Sisson TW, Mazdab FK (2007) Young cumulate complex beneath Veniaminof caldera, Aleutian arc, dated by zircon in erupted plutonic blocks. Geology 35(6):491-494. doi:10.1130/ G23446a.1

Barker DS (1987) Rhyolites Contaminated with metapelite and gabbro, Lipari, Aeolian Islands, Italy - products of lower crustal fusion or of assimilation plus fractional crystallization. Contrib Mineral Petrol 97(4):460-472. doi:10.1007/Bf00375324

Berndt J, Koepke J, Holtz F (2005) An experimental investigation of the influence of water and oxygen fugacity on differentiation of MORB at 200 MPa. J Petrol 46(1):135-167. doi:10.1093/ petrology/egh066

Bindeman I (2008) Oxygen isotopes in mantle and crustal magmas as revealed by single crystal analysis. Rev Mineral Geochem 69:445-478. doi:10.2138/Rmg.2008.69.12

Bindeman IN, Davis AM, Drake MJ (1998) Ion microprobe study of plagioclase-basalt partition experiments at natural concentration levels of trace elements. Geochim Cosmochim Acta 62(7):1175-1193. doi:10.1016/S0016-7037(98)00047-7

Blundy JD, Wood BJ (1991) Crystal-chemical controls on the partitioning of $\mathrm{Sr}$ and $\mathrm{Ba}$ between plagioclase feldspar, silicate 
melts, and hydrothermal solutions. Geochim Cosmochim Acta 55(1):193-209. doi:10.1016/0016-7037(91)90411-W

Bohrson WA, Reid MR (1997) Genesis of silicic peralkaline volcanic rocks in an ocean island setting by crustal melting and opensystem processes: Socorro Island, Mexico. J Petrol 38(9):11371166. doi:10.1093/Petrology/38.9.1137

Bowen N (1928) The evolution of the igneous rocks. Princeton University Press, Princeton

Brophy JG (1991) Composition gaps, critical crystallinity, and fractional crystallization in orogenic (calc-alkaline) magmatic systems. Contrib Mineral Petrol 109(2):173-182. doi:10.1007/ Bf00306477

Bunsen R (1851) Ueber die prozesse der vulkanishen Gesteinsbildungen Islands. Ann Phys 83:197-272

Cabero MT, Mecoleta S, Lopez-Moro FJ (2012) OPTIMASBA: A Microsoft Excel workbook to optimise the mass-balance modelling applied to magmatic differentiation processes and subsolidus overprints. Comput Geosci UK 42:206-211. doi:10.1016/J. Cageo.2011.10.013

Caggianelli A, Delmoro A, Paglionico A, Piccarreta G, Pinarelli L, Rottura A (1991) Lower Crustal granite genesis connected with chemical fractionation in the continental-crust of Calabria (Southern Italy). Eur J Mineral 3(1):159-180

Caricchi L, Burlini L, Ulmer P, Gerya T, Vassalli M, Papale P (2007) Non-Newtonian rheology of crystal-bearing magmas and implications for magma ascent dynamics. Earth Planet Sci Lett 264(3-4):402-419. doi:10.1016/j.eps1.2007.09.032

Chayes F (1963) Relative abundance of intermediate members of oceanic basalt-trachyte association. J Geophys Res 68(5):1519. doi:10.1029/Jz068i005p01519

Christiansen EH, McCurry M (2008) Contrasting origins of Cenozoic silicic volcanic rocks from the western Cordillera of the United States. Bull Volcanol 70(3):251-267. doi:10.1007/ S00445-007-0138-1

Cooper GF, Wilson CJN (2014) Development, mobilisation and eruption of a large crystal-rich rhyolite: the Ongatiti ignimbrite, New Zealand. Lithos 198-199:38-57. doi:10.1016/j. lithos.2014.03.014

Cox KG, Devey CW (1987) Fractionation processes in Deccan traps magmas-comments. J Petrol 28(1):235-238

Crisci GM, Derosa R, Esperanca S, Mazzuoli R, Sonnino M (1991) Temporal evolution of a 3 component system - the island of Lipari (Aeolian Arc, southern Italy). Bull Volcanol 53(3):207221. doi:10.1007/Bf00301231

Daly RA (1925) The geology of Ascension Island. Proc Am Acad Arts Sci 60(1/14):3-123. doi:10.2307/25130043

Davì M, De Rosa R, Barca D (2009) A LA-ICP-MS study of minerals in the Rocche Rosse magmatic enclaves: evidence of a mafic input triggering the latest silicic eruption of Lipari Island (Aeolian Arc, Italy). J Volcanol Geotherm Res 182(1-2):45-56. doi:10.1016/J.Jvolgeores.2009.02.001

Davì M, De Rosa R, Holtz F (2010) Mafic enclaves in the rhyolitic products of Lipari historical eruptions; relationships with the coeval Vulcano magmas (Aeolian Islands, Italy). Bull Volcanol 72(8):991-1008. doi:10.1007/S00445-010-0376-5

Davì M, De Rosa R, Donato P, Sulpizio R (2011) The Lami pyroclastic succession (Lipari, Aeolian Islands): a clue for unravelling the eruptive dynamics of the Monte Pilato rhyolitic pumice cone. J Volcanol Geotherm Res 201(1-4):285-300. doi:10.1016/J.Jvolgeores.2010.09.010

De Astis G, Lucchi F, Dellino P, La Volpe L, Tranne CA, Frezzotti ML, Peccerillo A (2013) Geology, volcanic history and petrology of Vulcano (central Aeolian archipelago). Geol Soc Mem 37:281-349. doi:10.1144/M37.11

De Rosa R, Donato P, Gioncada A, Masetti M, Santacroce R (2003) The Monte Guardia eruption (Lipari, Aeolian Islands): an example of a reversely zoned magma mixing sequence. Bull Volcanol 65(7):530-543. doi:10.1007/S00445-003-0281-2

Deering CD (2009) Cannibalization of an amphibole-rich andesitic progenitor induced by caldera-collapse during the Matahina eruption: evidence from amphibole compositions. Am Mineral 94(8-9):1162-1174. doi:10.2138/ Am.2009.3135

Deering CD, Bachmann O (2010) Trace element indicators of crystal accumulation in silicic igneous rocks. Earth Planet Sci Lett 297(1-2):324-331. doi:10.1016/J.Eps1.2010.06.034

Deering CD, Bachmann O, Dufek J, Gravley DM (2011a) Rift-related transition from andesite to rhyolite volcanism in the Taupo Volcanic Zone (New Zealand) controlled by crystal-melt dynamics in mush zones with variable mineral assemblages. J Petrol 52(11):2243-2263. doi:10.1093/Petrology/Egr046

Deering CD, Bachmann O, Vogel TA (2011b) The ammonia tanks tuff: erupting a melt-rich rhyolite cap and its remobilized crystal cumulate. Earth Planet Sci Lett 310(3-4):518-525. doi:10.1016/J.Eps1.2011.08.032

Deering CD, Cole JW, Vogel TA (2011c) Extraction of crystal-poor rhyolite from a hornblende-bearing intermediate mush: a case study of the caldera-forming Matahina eruption, Okataina volcanic complex. Contrib Mineral Petrol 161(1):129-151. doi:10.1007/s00410-010-0524-0

Depaolo DJ (1981) Trace-element and isotopic effects of combined wallrock assimilation and fractional crystallization. Earth Planet Sci Lett 53(2):189-202. doi:10.1016/0012-821x(81)90153-9

Di Martino C, Frezzotti ML, Lucchi F, Peccerillo A, Tranne CA, Diamond LW (2010) Magma storage and ascent at Lipari Island (Aeolian archipelago, Southern Italy) at 223-81 ka: the role of crustal processes and tectonic influence. Bull Volcanol 72(9):1061-1076. doi:10.1007/S00445-010-0383-6

Di Martino C, Forni F, Frezzotti ML, Palmeri R, Webster JD, Ayuso RA, Lucchi F, Tranne CA (2011) Formation of cordieritebearing lavas during anatexis in the lower crust beneath Lipari Island (Aeolian arc, Italy). Contrib Mineral Petrol 162(5):10111030. doi:10.1007/S00410-011-0637-0

Dufek J, Bachmann O (2010) Quantum magmatism: magmatic compositional gaps generated by melt-crystal dynamics. Geology 38(8):687-690. doi:10.1130/G30831.1

Dufek J, Bergantz GW (2005) Lower crustal magma genesis and preservation: a stochastic framework for the evaluation of basaltcrust interaction. J Petrol 46(11):2167-2195. doi:10.1093/ Petrology/Egi049

Eichelberger JC, Izbekov PE, Browne BL (2006) Bulk chemical trends at arc volcanoes are not liquid lines of descent. Lithos 87(1-2):135-154. doi:10.1016/J.Lithos.2005.05.006

Ellis BS, Bachmann O, Wolff JA (2014) Cumulate fragments in silicic ignimbrites: the case of the Snake River Plain. Geology 42(5):431-434. doi:10.1130/G35399.1

Esperanca S, Crisci GM, Derosa R, Mazzuoli R (1992) The role of the crust in the magmatic evolution of the Island of Lipari (Aeolian Islands, Italy). Contrib Mineral Petr 112(4):450-462. doi:10.1007/Bf00310777

Forni F, Lucchi F, Peccerillo A, Tranne CA, Rossi PL, Frezzotti ML (2013) Stratigraphy and geological evolution of the Lipari volcanic complex (central Aeolian archipelago). Geol Soc Mem 37:213-279. doi:10.1144/M37.10

Francalanci L, Varekamp JC, Vougioukalakis G, Defant MJ, Innocenti F, Manetti P (1995) Crystal retention, fractionation and crustal assimilation in a convecting magma chamber, Nisyros Volcano, Greece. Bull Volcanol 56(8):601-620

Francalanci L, Lucchi F, Keller J, De Astis G, Tranne CA (2013) Eruptive, volcano-tectonic and magmatic history of the Stromboli volcano (north-eastern Aeolian archipelago). Geol Soc Mem 37:397-471. doi:10.1144/M37.13 
Francis PW, Thorpe RS, Moorbath S, Kretzschmar GA, Hammill M (1980) Strontium isotope evidence for crustal contamination of calc-alkaline volcanic-rocks from Cerro-Galan, Northwest Argentina. Earth Planet Sci Lett 48(2):257-267. doi:10.1016/0012-821x(80)90189-2

Geist D, Howard KA, Larson P (1995) The generation of oceanic rhyolites by crystal fractionation-the basalt-rhyolite association at Volcan-Alcedo, Galapagos-Archipelago. J Petrol 36(4):965-982

Gelman SE, Deering CD, Bachmann O, Huber C, Gutiérrez FJ (2014) Identifying the crystal graveyards remaining after large silicic eruptions. Earth Planet Sci Lett 403:299-306. doi:10.1016/j. eps1.2014.07.005

Gioncada A, Clocchiatti R, Sbrana A, Bottazzi P, Massare D, Ottolini L (1998) A study of melt inclusions at Vulcano (Aeolian Islands, Italy): insights on the primitive magmas and on the volcanic feeding system. Bull Volcanol 60(4):286-306. doi: $10.1007 /$ S004450050233

Gioncada A, Mazzuoli R, Bisson M, Pareschi MT (2003) Petrology of volcanic products younger than $42 \mathrm{ka}$ on the Lipari-Vulcano complex (Aeolian Islands, Italy): an example of volcanism controlled by tectonics. J Volcanol Geotherm Res 122(3-4):191220. doi:10.1016/S0377-0273(02)00502-4

Gioncada A, Mazzuoli R, Milton AJ (2005) Magma mixing at Lipari (Aeolian Islands, Italy): insights from textural and compositional features of phenocrysts. J Volcanol Geotherm Res 145(12):97-118. doi:10.1016/J.Jvolgeores.2005.01.002

Guillong M, Meier DL, Allan MM, Heinrich CA, Yardley BWD (2008) SILLS: a MATLAB-based program for the reduction of laser ablation ICP-MS data of homogeneous materials and inclusions. Mineral Assoc Can Short Course 40:328-333

Haase KA, Stroncik N, Garbe-Schnoberg D, Stoffers P (2006) Formation of island are dacite magmas by extreme crystal fractionation: an example from Brothers Seamount, Kermadec island arc (SW Pacific). J Volcanol Geotherm Res 152(3-4):316-330. doi:10.1016/J.Jvolgeores.2005.10.010

Halliday AN, Davidson JP, Hildreth W, Holden P (1991) Modeling the petrogenesis of high $\mathrm{Rb} / \mathrm{Sr}$ silicic magmas. Chem Geol 92(1-3):107-114. doi:10.1016/0009-2541(91)90051-R

Harker A (1909) The natural history of igneous rocks. Methuen, London

Hildreth W (2004) Volcanological perspectives on Long Valley, Mammoth Mountain, and Mono Craters: several contiguous but discrete systems. J Volcanol Geotherm Res 136(3-4):169-198. doi:10.1016/J.Volgrores.2004.05.019

Hildreth W, Fierstein J (2000) Katmai volcanic cluster and the great eruption of 1912. Geol Soc Am Bull 112(10):1594-1620. doi:10.1130/0016-7606(2000)112<1594:Kvcatg >2.0.Co;2

Kerr AC, Kempton PD, Thompson RN (1995) Crustal assimilation during turbulent magma ascent (Ata) —new isotopic evidence from the mull tertiary lava succession, NW Scotland. Contrib Mineral Petrol 119(2-3):142-154. doi:10.1007/Bf00307277

Lee CTA, Bachmann O (2014) How important is the role of crystal fractionation in making intermediate magmas? insights from $\mathrm{Zr}$ and $\mathrm{P}$ systematics. Earth Planet Sci Lett 393:266-274. doi:10.1016/J.Epsl.2014.02.044

Lee CTA, Morton DM (2015) High silica granites: terminal porosity and crystal settling in shallow magma chambers. Earth Planet Sci Lett 409:23-31. doi:10.1016/J.Epsl.2014.10.040

Lindsay JM, Schmitt AK, Trumbull RB, De Silva SL, Siebel W, Emmermann R (2001) Magmatic evolution of the La Pacana caldera system, Central Andes, Chile: compositional variation of two cogenetic, large-volume felsic ignimbrites. J Petrol 42(3):459-486. doi:10.1093/Petrology/42.3.459

Lipman PW (2007) Incremental assembly and prolonged consolidation of Cordilleran magma chambers: evidence from the
Southern Rocky Mountain volcanic field. Geosphere 3(1):4270. doi:10.1130/Ges00061.1

Lucchi F, Gertisser R, Keller J, Forni F, De Astis G, Tranne CA (2013a) Eruptive history and magmatic evolution of the island of Salina (central Aeolian archipelago). Geol Soc Mem 37:155211. doi:10.1144/M37.9

Lucchi F, Peccerillo A, Tranne CA, Rossi PL, Frezzotti ML, Donati C (2013b) Volcanism, calderas and magmas of the Alicudi composite volcano (western Aeolian archipelago). Geol Soc Mem 37:83-111. doi:10.1144/M37.7

Lucchi F, Santo AP, Tranne CA, Peccerillo A, Keller J (2013c) Volcanism, magmatism, volcano-tectonics and sea-level fluctuations in the geological history of Filicudi (western Aeolian archipelago). Geol Soc Mem 37:113-153. doi:10.1144/M37.8

Lucchi F, Tranne CA, Peccerillo A, Keller J, Rossi PL (2013d) Geological history of the Panarea volcanic group (eastern Aeolian archipelago). Geol Soc Mem 37:351-395. doi:10.1144/M37.12

Mckenzie D (1985) The extraction of magma from the crust and mantle. Earth Planet Sci Lett 74(1):81-91. doi:10.1016/0012-821x(85)90168-2

Mushkin A, Stein M, Halicz L, Navon O (2002) The Daly gap: lowpressure fractionation and heat-loss from cooling magma chamber. Geochim Cosmochim Acta 66(15A):A539-A539

Nagasawa H (1973) Rare-earth distribution in alkali rocks from OkiDogo-Island, Japan. Contrib Mineral Petrol 39(4):301-308. doi:10.1007/Bf00376470

Nash WP, Crecraft HR (1985) Partition-coefficients for trace-elements in silicic magmas. Geochim Cosmochim Acta 49(11):2309 2322. doi:10.1016/0016-7037(85)90231-5

Peccerillo A, Taylor SR (1976) Geochemistry of Eocene calc-alkaline volcanic-rocks from Kastamonu Area, Northern Turkey. Contrib Mineral Petrol 58(1):63-81. doi:10.1007/Bf00384745

Peccerillo A, Barberio MR, Yirgu G, Ayalew D, Barbieri M, Wu TW (2003) Relationships between mafic and peralkaline silicic magmatism in continental rift settings: a petrological, geochemical and isotopic study of the Gedemsa volcano, central Ethiopian rift. J Petrol 44(11):2003-2032. doi:10.1093/Petrology/Egg068

Peccerillo A, Dallai L, Frezzotti ML, Kempton PD (2004) Sr-Nd$\mathrm{Pb}-\mathrm{O}$ isotopic evidence for decreasing crustal contamination with ongoing magma evolution at Alicudi volcano (Aeolian arc, Italy): implications for style of magma-crust interaction and for mantle source compositions. Lithos 78(1-2):217-233. doi:10.1016/j.lithos.2004.04.040

Peccerillo A, Frezzotti ML, De Astis G, Ventura G (2006) Modeling the magma plumbing system of Vulcano (Aeolian Islands, Italy) by integrated fluid-inclusion geobarometry, petrology, and geophysics. Geology 34(1):17-20. doi:10.0030/G22117.1

Peccerillo A, Donati C, Santo AP, Orlando A, Yirgu G, Ayalew D (2007) Petrogenesis of silicic peralkaline rocks in the Ethiopian rift: geochemical evidence and volcanological implications. J Afr Earth Sci 48(2-3):161-173. doi:10.1016/j. jafrearsci.2006.06.010

Peccerillo A, De Astis G, Faraone D, Forni F, Frezzotti ML (2013) Compositional variations of magmas in the Aeolian arc: implications for petrogenesis and geodynamics. Geol Soc Mem 37:491-510. doi:10.1144/M37.15

Perugini D, Valentini L, Poli G (2007) Insights into magma chamber processes from the analysis of size distribution of enclaves in lava flows: a case study from Vulcano Island (Southern Italy). J Volcanol Geotherm Res 166(3-4):193-203. doi:10.1016/J. Jvolgeores.2007.07.017

Piochi M, De Astis G, Petrelli M, Ventura G, Sulpizio R, Zanetti A (2009) Constraining the recent plumbing system of Vulcano (Aeolian Arc, Italy) by textural, petrological, and fractal analysis: the 1739 AD Pietre Cotte lava flow. Geochem Geophys Geosyst 10:Q01009. doi:10.1029/2008gc002176 
Piromallo C, Morelli A (2003) P wave tomography of the mantle under the Alpine-Mediterranean area. J Geophys Res Solid Earth 108(B2):2065. doi:10.1029/2002jb001757

Pistone M, Arzilli F, Dobson KJ, Cordonnier B, Reusser E, Ulmer P, Marone F, Whittington AG, Mancini L, Fife JL, Blundy JD (2015) Gas-driven filter pressing in magmas: insights into in situ melt segregation from crystal mushes. Geology 43(8):699-702. doi:10.1130/G36766.1

Poli G, Miller JS, Wooden JL, Perugini D, Mazdab F (2008) Insights on the genesis and thermal evolution of rhyolitic magmas beneath Lipari Island (Aeolian Islands, Italy) by ion microprobe U/Th dating and trace element analysis of zircon. Geophysical Research Abstracts, EGU General Assembly, vol 10

Portnyagin M, Hoernle K, Storm S, Mironov N, van den Bogaard C, Botcharnikov R (2012) $\mathrm{H}_{2} \mathrm{O}$-rich melt inclusions in fayalitic olivine from Hekla volcano: implications for phase relationships in silicic systems and driving forces of explosive volcanism on Iceland. Earth Planet Sci Lett 357-358:337-346. doi:10.1016/j. eps1.2012.09.047

Price RC, Gamble JA, Smith IEM, Stewart RB, Eggins S, Wnight IC (2005) An integrated model for the temporal evolution of andesites and rhyolites and crustal development in New Zealand's North Island. J Volcanol Geotherm Res 140(1-3):1-24. doi:10.1016/J.Jvolgeores.2004.07.013

Putirka K (2008) Thermometers and barometers for volcanic systems. Rev Mineral Geochem 69:61-120

Rollinson HR (1993) Using geochemical data: evaluation, presentation, interpretation. Taylor \& Francis, London

Santo AP, Peccerillo A (2008) Oxygen isotopic variations in the clinopyroxene from the Filicudi Volcanic Rocks (Aeolian Island, Italy): implications for open-system magma evolution. Open Mineral J 2:22-33

Schmitt AK, Hulen JB (2008) Buried rhyolites within the active, high-temperature Salton Sea geothermal system. J Volcanol Geotherm Res 178(4):708-718. doi:10.1016/J. Jvolgeores.2008.09.001

Shane P, Nairn IA, Smith VC (2005) Magma mingling in the similar to $50 \mathrm{ka}$ Rotoiti eruption from Okataina Volcanic Centre: implications for geochemical diversity and chronology of large volume rhyolites. J Volcanol Geotherm Res 139(3-4):295-313. doi:10.1016/J.Jvolgeores.2004.08.012

Sharp ZD (1990) A laser-based microanalytical method for the in situ determination of oxygen isotope ratios of silicates and oxides. Geochim Cosmochim Acta 54(5):1353-1357. doi:10.1016/0016-7037(90)90160-M

Sharp ZD, Frey M, Livi KJT (1995) Stable-isotope variations (H, C, $\mathrm{O})$ in a prograde metamorphic triassic red-bed formation, Central Swiss Alps. Schweiz Mineral Petrogr 75(2):147-161

Simon JI, Weis D, DePaolo DJ, Renne PR, Mundil R, Schmitt AK (2014) Assimilation of preexisting Pleistocene intrusions at Long Valley by periodic magma recharge accelerates rhyolite generation: rethinking the remelting model. Contrib Mineral Petrol 167(1):955. doi:10.1007/S00410-013-0955-5

Smith IEM, Worthington TJ, Price RC, Stewart RB, Maas R (2006) Petrogenesis of dacite in an oceanic subduction environment: Raoul Island, Kermadec arc. J Volcanol Geotherm Res 156(34):252-265. doi:10.1016/J.Jvolgeores.03.003

Sun S-S, McDonough WF (1989) Chemical and isotopic systematics of oceanic basalts: implications for mantle composition and processes. Geological Society, London, Special Publications No 42(1), pp 313-345. doi:10.1144/gsl.sp.1989.042.01.19

Szymanowski D, Ellis BS, Bachmann O, Guillong M, Phillips WM (2015) Bridging basalts and rhyolites in the YellowstoneSnake River Plain volcanic province: the elusive intermediate step. Earth Planet Sci Lett 415:80-89. doi:10.1016/j. eps1.2015.01.041
Tamura Y, Gill JB, Tollstrup D, Kawabata H, Shukuno H, Chang Q, Miyazaki T, Takahashi T, Hirahara Y, Kodaira S, Ishizuka O, Suzuki T, Kido Y, Fiske RS, Tatsumi Y (2009) Silicic magmas in the Izu-Bonin Oceanic Arc and implications for crustal evolution. J Petrol 50(4):685-723. doi:10.1093/Petrology/Egp017

Tanaka T, Togashi S, Kamioka H, Amakawa H, Kagami H, Hamamoto T, Yuhara M, Orihashi Y, Yoneda S, Shimizu H, Kunimaru T, Takahashi K, Yanagi T, Nakano T, Fujimaki H, Shinjo R, Asahara Y, Tanimizu M, Dragusanu C (2000) JNdi-1: a neodymium isotopic reference in consistency with LaJolla neodymium. Chem Geol 168(3-4):279-281. doi:10.1016/S0009-2541(00)00198-4

Taylor HP (1980) The effects of assimilation of country rocks by magmas on O-18-O-16 and Sr-87-Sr-86 systematics in igneous rocks. Earth Planet Sci Lett 47(2):243-254. doi:10.1016/0012-821x(80)90040-0

Thompson G, Smith I, Malpas J (2001) Origin of oceanic phonolites by crystal fractionation and the problem of the Daly gap: an example from Rarotonga. Contrib Mineral Petrol 142(3):336346. doi:10.1007/s004100100294

Thompson AB, Matile L, Ulmer P (2002) Some thermal constraints on crustal assimilation during fractionation of hydrous, mantlederived magmas with examples from central alpine batholiths. J Petrol 43(3):403-422. doi:10.1093/Petrology/43.3.403

Todt W, Cliff RA, Hanser A, Hofmann AW (1993) Recalibration of NBS lead standards using a $207 \mathrm{~Pb} / 205 \mathrm{~Pb}$ double spike. Terra Abstracts 5:396

Trua T, Deniel C, Mazzuoli R (1999) Crustal control in the genesis of Plio-Quaternary bimodal magmatism of the Main Ethiopian Rift (MER): geochemical and isotopic ( $\mathrm{Sr}, \mathrm{Nd}, \mathrm{Pb}$ ) evidence. Chem Geol 155(3-4):201-231. doi:10.1016/S0009-2541(98)00174-0

Valley JW, Chiarenzelli JR, Mclelland JM (1994) Oxygen-isotope geochemistry of Zircon. Earth Planet Sci Lett 126(4):187-206. doi:10.1016/0012-821x(94)90106-6

Valley JW, Bindeman IN, Peck WH (2003) Empirical calibration of oxygen isotope fractionation in zircon. Geochim Cosmochim Acta 67(17):3257-3266. doi:10.1016/S0016-7037(00)00090-5

Ventura G (2013) Kinematics of the Aeolian volcanism (Southern Tyrrhenian Sea) from geophysical and geological data. Geol Soc Mem 37:3-11. doi:10.1144/M37.2

Ventura G, Vilardo G, Milano G, Pino NA (1999) Relationships among crustal structure, volcanism and strike-slip tectonics in the Lipari-Vulcano Volcanic Complex (Aeolian Islands, Southern Tyrrhenian Sea, Italy). Phys Earth Planet Inter 116(1-4):3152. doi:10.1016/S0031-9201(99)00117-X

Villemant B (1988) Trace-element evolution in the Phlegrean fields (Central-Italy) - fractional crystallization and selective enrichment. Contrib Mineral Petrol 98(2):169-183. doi:10.1007/Bf00402110

Wade JA, Plank T, Stern RJ, Tollstrup DL, Gill JB, O'Leary JC, Eiler JM, Moore RB, Woodhead JD, Trusdell F, Fischer TP, Hilton DR (2005) The May 2003 eruption of Anatahan volcano, Mariana Islands: geochemical evolution of a silicic islandarc volcano. J Volcanol Geotherm Res 146(1-3):139-170. doi:10.1016/J.Jvolgeores.2004.11.035

Watson EB, Harrison TM (1983) Zircon saturation revisitedtemperature and composition effects in a variety of crustal magma types. Earth Planet Sci Lett 64(2):295-304. doi:10.1016/0012-821x(83)90211-X

Wiesmaier S, Troll VR, Carracedo JC, Ellam RM, Bindeman I, Wolff JA (2012) Bimodality of lavas in the Teide-Pico Viejo succession in Tenerife - the role of crustal melting in the origin of recent phonolites. J Petrol 53(12):2465-2495. doi:10.1093/ Petrology/Egs056

Wolff JA, Ellis BS, Ramos FC, Starkel WA, Boroughs S, Olin PH, Bachmann O (2015) Remelting of cumulates as a process for producing chemical zoning in silicic tuffs: a comparison of cool, wet and hot, dry rhyolitic magma systems. Lithos 236 237:275-286. doi:10.1016/j.lithos.2015.09.002 